\title{
Glacial and palaeoenvironmental history of the Cape Chelyuskin area, Arctic Russia
}

\author{
Per Möller ${ }^{1}$, Grigorij Fedorov ${ }^{2}$, Maxim Pavlov², Marit-Solveig Seidenkrantz ${ }^{3}$ \& Charlotte Sparrenbom ${ }^{4}$ \\ 1 Quaternary Sciences, Dept. of Geology, GeoBiosphere Science Centre, Lund University, Sölvegatan 12, SE-22362 Lund, Sweden \\ 2 Arctic and Antarctic Research Institute, 38 Bering Street, RU-199397 St. Petersburg, Russia \\ 3 Dept. of Earth Science, University of Aarhus, Høegh-Guldbergs Gade 2, DK-8000 Århus, Denmark \\ 4 Swedish Geotechnical Institute, Hospitalsgatan 16A, SE-21133 Malmö, Sweden
}

\section{Keywords}

Eemian; glacial geology; glacial stratigraphy; Kara Sea ice sheet; Siberia.

\section{Correspondence}

Per Möller, Quaternary Sciences, Dept. of Geology, GeoBiosphere Science Centre, Lund University, Sölvegatan 12, SE-22362 Lund, Sweden. E-mail: per.moller@geol.lu.se

doi:10.1111/j.1751-8369.2008.00066.x

\begin{abstract}
Quaternary glacial stratigraphy and relative sea-level changes reveal at least two glacial expansions over the Chelyuskin Peninsula, bordering the Kara Sea at about $77^{\circ} \mathrm{N}$ in the Russian Arctic, as indicated from tills interbedded with marine sediments, exposed in stratigraphic superposition, and from raisedbeach sequences mapped to altitudes of at least up to ca. $80 \mathrm{~m}$ a.s.l. Chronological control is provided by accelerator mass spectrometry ${ }^{14} \mathrm{C}$ dating, electron-spin resonance and optically stimulated luminescence geochronology. Major glaciations, followed by deglaciation and marine inundation, occurred during marine oxygen isotope stages 6-5e (MIS 6-5e) and stages MIS 5d-5c. These glacial sediments overlie marine sediments of Pliocene age, which are draped by fluvial sediment of a pre-Saalian age, thereby forming palaeovalley/ basin fills in the post-Cretaceous topography. Till fabrics and glacial tectonics record expansions of local ice caps exclusively, suggesting wet-based ice cap advance, followed by cold-based regional ice-sheet expansion. Local ice caps over highland sites along the perimeter of the shallow Kara Sea, including the Byrranga Mountains and the Severnaya Zemlya archipelago, appear to have repeatedly fostered initiation of a large Kara Sea ice sheet, with the exception of the Last Glacial Maximum (MIS 2), when Kara Sea ice neither impacted the Chelyuskin Peninsula nor Severnaya Zemlya, and barely touched the northern coastal areas of the Taymyr Peninsula.
\end{abstract}

An understanding of spatial and temporal variations of past Eurasian High Arctic ice sheets is essential for reconstructing Quaternary climates, ocean current fluctuations and the fluxes of freshwater to the Arctic Ocean, and for constraining sea levels (Peltier 1994; Weaver 1995; Forman et al. 2000). Extensive field research over the past 10-15 years, summarized by Svendsen et al. (1999), Svendsen et al. (2004) and Larsen et al. (2006), and used as a basis for modelling by Siegert \& Dowdeswell (2004) and Lambeck et al. (2006), has led to reconstructions of a substantially larger ice sheet in the Barents Sea (BSIS) than the Kara Sea (KSIS) during the Last Glacial Maximum (LGM) (Fig. la). There is also a growing consensus that successively smaller ice volumes have occupied the Kara Sea basin since marine oxygen isotope stage 6 (MIS 6).
Despite recent progress, uncertainty remains as to the reconstruction of the ice extent and ice dynamics of the LGM and pre-LGM ice sheets in the Kara-Barents seas region, especially in the enigmatic northern Kara Sea, and its adjacent land areas. As an example, there is very little evidence of an LGM ice sheet, except from observations provided by Alexanderson et al. (2001), which indicated that ice advanced from the north onto low-lying coastal areas of the north-western Taymyr Peninsula (Fig. la) between 20 and 12 Kya. Even larger uncertainties exist with reconstructions of the maximum extent and ice dynamics of pre-LGM ice sheets in the northern Kara Sea region, because the records are often fragmentary, difficult to date or far inside the terminal ice margins. (Astakhov 2001, 2004). Möller et al. (1999) and Alexanderson et al. (2002) concluded that northern Taymyr was subjected to 

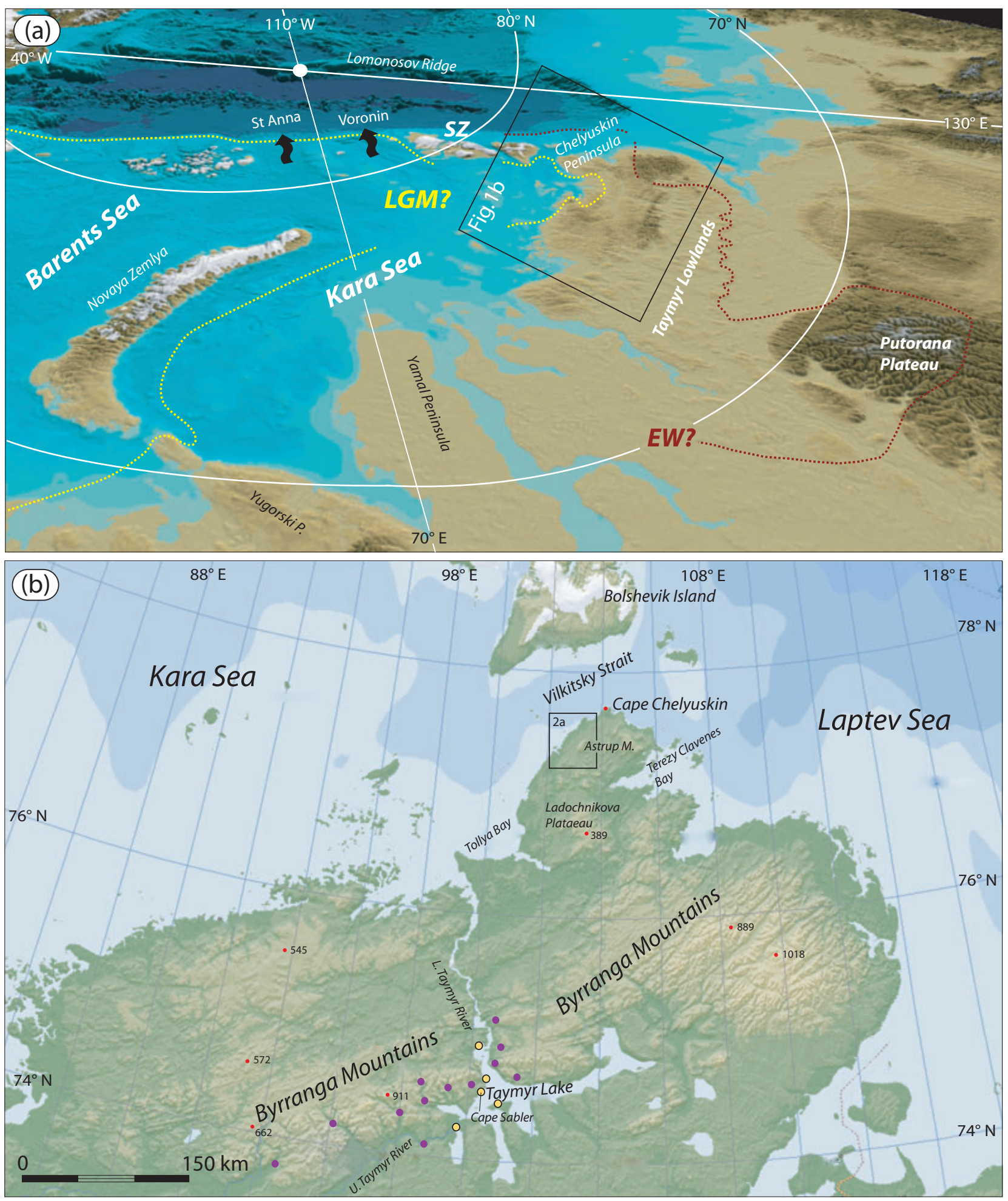

Fig. 1 (a) Location map of north-western Siberia and the adjoining Arctic Ocean. (The three-dimensional view is courtesy of Martin Jakobsson; bathymetry is based on Jakobsson \& Cherkis 2001; see also Jakobsson et al. 2000.) The configurations of the Eurasian ice sheet at the Last Glacial Maximum and the Early Weichselian are according to Svendsen et al. (2004). (b) Location and topographic map of the northern Taymyr Peninsula. The insert frame indicates the position of the map shown in Fig. 2a. Violet dots are locations with marine deposits from the Early Weichselian deglaciation (90-70 Kya) along the southern slopes of the Byrranga Mountains; the yellow dots are localities with organic-rich Cape Sabler-type deposits from 40-10 Kya (Möller et al. 1999; Hjort et al. 2004). 
extensive glaciations in Early to Middle Weichselian times (ca. 90-80 and 70-60 Kya; MIS 5 and MIS 4) (Fig. la), but evidence of older glaciations is sparse. Recently, however, evidence of multiple pre-LGM glaciations has been presented from Severnaya Zemlya (Möller et al. 2006). Tills interbedded with marine sediments, all exposed in stratigraphic superposition, and from raised-beach sequences that occur at altitudes up to $140 \mathrm{~m}$ a.s.l., suggest at least four expansions of Kara Sea ice sheets over the Severnaya Zemlya archipelago. Major glaciations, followed by deglaciation and marine inundations, occurred during MIS 10-9, MIS 8-7, MIS 6-5e and MIS 5d-3. The MIS 6-5e event, associated with the highest marine limit, implies ice-sheet thickness of $>2000 \mathrm{~m}$ only $200 \mathrm{~km}$ from the deep Arctic Ocean. This concurs with evidence for ice grounding at a depth of $1000 \mathrm{~m}$ along the Lomonosov Ridge in the central Arctic Ocean (Fig. la) by a thick ice shelf or by enormous icebergs at this time (Jakobsson et al. 2001; Polyak et al. 2001; Jakobsson et al. 2008). Understanding the ice sheet geometry associated with this grounding event has been difficult because of the paucity of MIS 6 data from ice-proximal areas on the shelves and adjacent land areas. Ice dynamics of such an event and during smaller glaciations in the region are no doubt complicated, and are influenced by factors like the inflow of Atlantic water to the Arctic basin, which provides critical moisture to the ice sheets.

Complicating things further is the fact that studies in Severnaya Zemlya (Möller et al. 2006), the western Taymyr Peninsula (Hjort \& Funder 2008 [this issue]), the Yugorski Peninsula (Lokrantz et al. 2003) and the western Yamal Peninsula (Forman et al. 1999, 2002) all indicate that initial KSIS growth began with the formation of local ice caps along the perimeter of the Kara Sea, which later coalesced on the adjacent shelf during globally falling sea levels. As a large KSIS dome eventually formed, there was a redistribution of ice drainage and basal thermal regimes, with the development of ice streams along the Voronin and St. Anna troughs (Fig. 1a). The southward expansion of the ice impinged on the Taymyr Peninsula and crossed the Byrranga Mountains (Möller et al. 2006).

From previous studies on the Taymyr Peninsula, we know that ice recession from the Early Weichselian maximum position northwards took place in a marine basin, as demonstrated from several localities with deepmarine to deltaic sediments in the Taymyr Lake basin, with topset beds reaching 100-120 m a.s.l. (Fig. 1b; Möller et al. 1999; Hjort et al. 2004). There are no signs of any glaciation reaching south of the Byrranga Mountains since then (e.g., Möller et al. 1999; Hjort et al. 2004), and the Byrranga mountains and the Taymyr Lake basin have thus been continuously ice-free since the Early Weichselian. This is, among other things, illustrated by a number of lacustrine/bog/aeolian sediment sequences, such as those at Cape Sabler, on the northern shore of Lake Taymyr (Kind \& Leonov 1982; Möller et al. 1999), with basal ages often being $>40 \mathrm{Ky}$, and showing continuous deposition up to the Holocene (Fig. 2a).

In the reconstruction of the KSIS through geologic time, the Chelyuskin Peninsula stands as one of the important pieces in the puzzle. Cape Chelyuskin $\left(77^{\circ} 43^{\prime} \mathrm{N}\right.$ $104^{\circ} 15^{\prime} \mathrm{E}$; Fig. 2b) forms the northernmost tip of the Taymyr Peninsula, and therefore of the Eurasian mainland. It is bordered to the north-west by the Kara Sea, to the north-east by the Laptev Sea and to the south by the Byrranga Mountains, the latter forming the backbone of the Taymyr Peninsula. The Severnaya Zemlya archipelago, with its centre on October Revolution Island, situated about $260 \mathrm{~km}$ to the north-west on the shallow Kara Sea shelf ( $<100 \mathrm{~m}$ of water depth), is separated from Cape Chelyuskin by the ca. 200-m-deep Vilkitsky Strait. The glacial stratigraphy on the Chelyuskin Peninsula thereby provides information on advances and retreats of the easternmost flank of the KSIS.

\section{Geography, geology and a lithostratigraphic overview of the Cape Chelyuskin area}

The west coast of the Chelyuskin Peninsula bordering the Kara Sea forms a flat coastal plain, approximately $10 \mathrm{~km}$ wide. It rises gently to about $80 \mathrm{~m}$ a.s.l. where it meets the plateau-topped Astrup Mountain, reaching some $300 \mathrm{~m}$ a.s.l. (Figs. 2a, 3b). The coastal areas consist primarily of Upper Jurassic and Lower Cretaceous sandstones, whereas the Astrup Mountain in the east consists of flysch deposits of Upper Proterozoic age, but also Palaeozoic granites (State geological map of the Russian Federation 2000).

Not much is previously known concerning the detailed Quaternary stratigraphy of this area. Early Russian studies, which were more reconnaissance-like, report widespread glacial deposits of Zyryansk age (undifferentiated early part of the Weichselian) draping interglacial marine sediments, the Ladochnikova Plateau (Fig. 1b) being the centre of glaciation on the Chelyuskin Peninsula (e.g., Mirošnikov 1959). Generalized stratigraphic section drawings (e.g., Ravič 1950; Puminov 1952; Mirošnikov 1959) indicate marine deposits of interglacial age (containing warmer-than-now indicator molluscs such as, e.g., Pecten islandicus [now Chlamys islandicus], Neptunea despecta v. denselirata and Balanus hameri v. sibirica) up to altitudes of 90-120 m a.s.l., lying on top of what are described as deposits of the maximal glaciation (Puminov 1952). Šnejder (1989) reported successions of marine and glaciomarine deposits, presumably (not dated) of Kazantzevo age (Eemian), forming marine terraces between 40 and $140 \mathrm{~m}$ a.s.l. in the Serebryanka River 

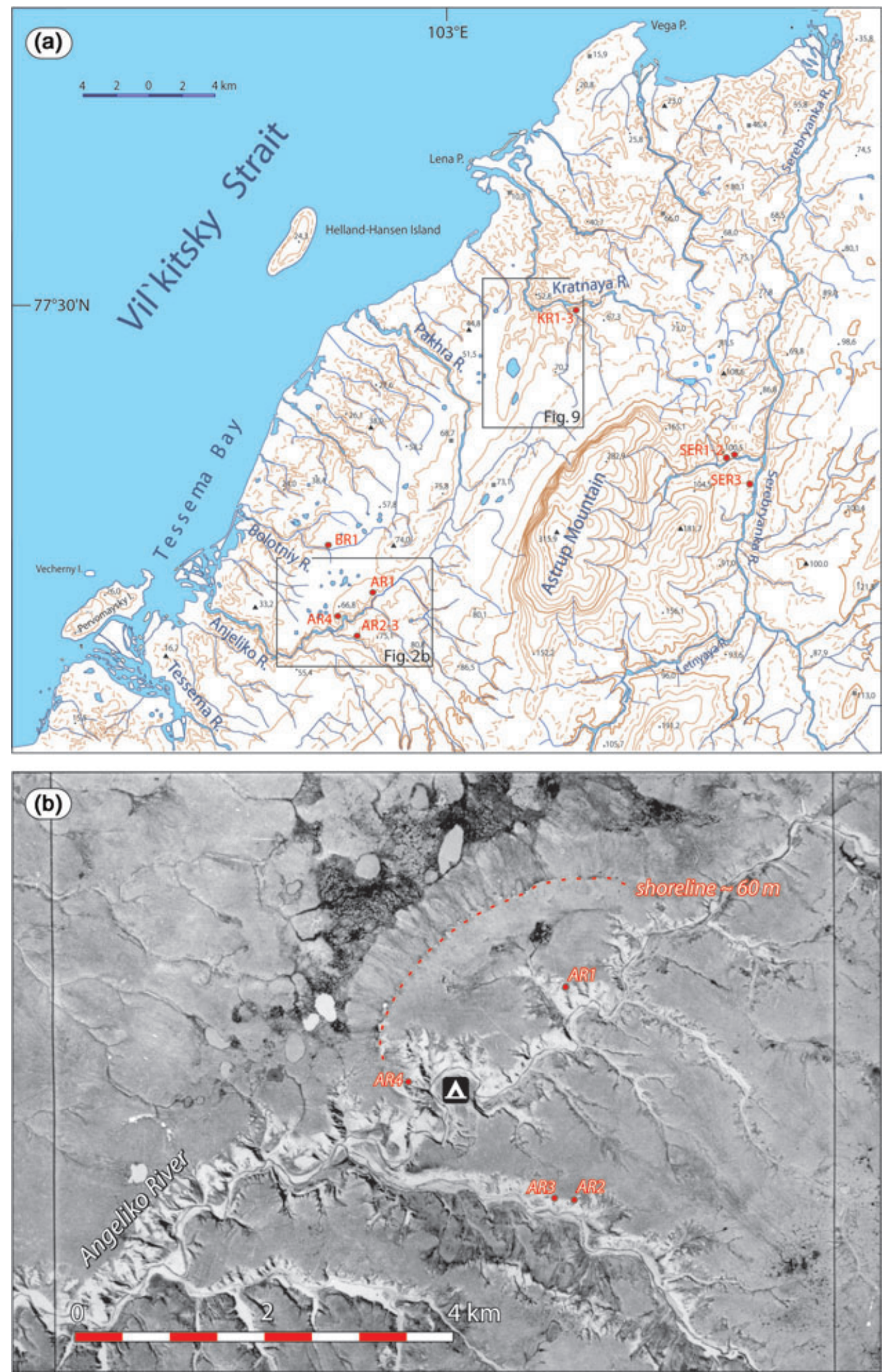

Fig. 2 (a) Map of the north-western coastal area of the Chelyuskin Peninsula, indicating the positions of logged sites along the Anjeliko, Bolotniy, Kratnaya and Serebryanka river valleys. (b) Aerial photograph of the upper Anjeliko River valley and its tributaries, showing the position of the sedimentologically investigated sites (AR1-4). Note the prominent shore terrace at ca. $60 \mathrm{~m}$ a.s.l., facing north-west. 

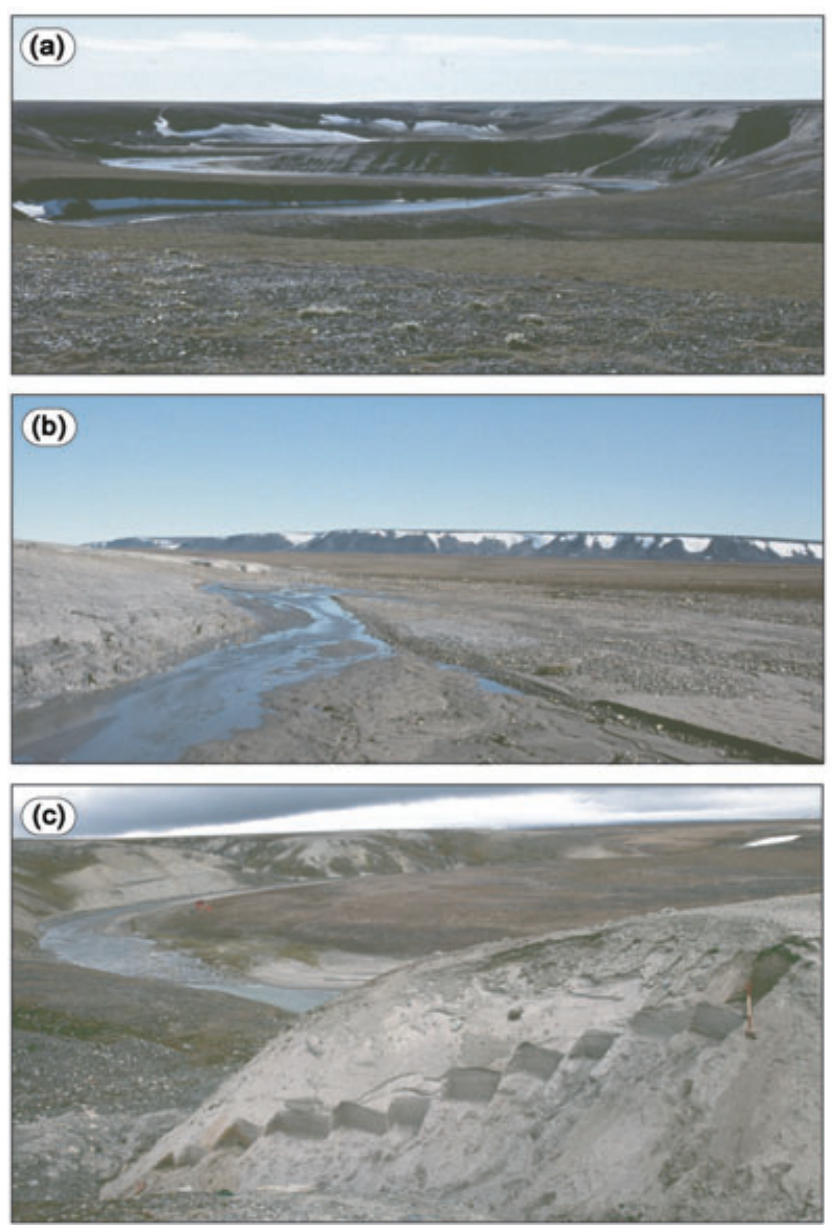

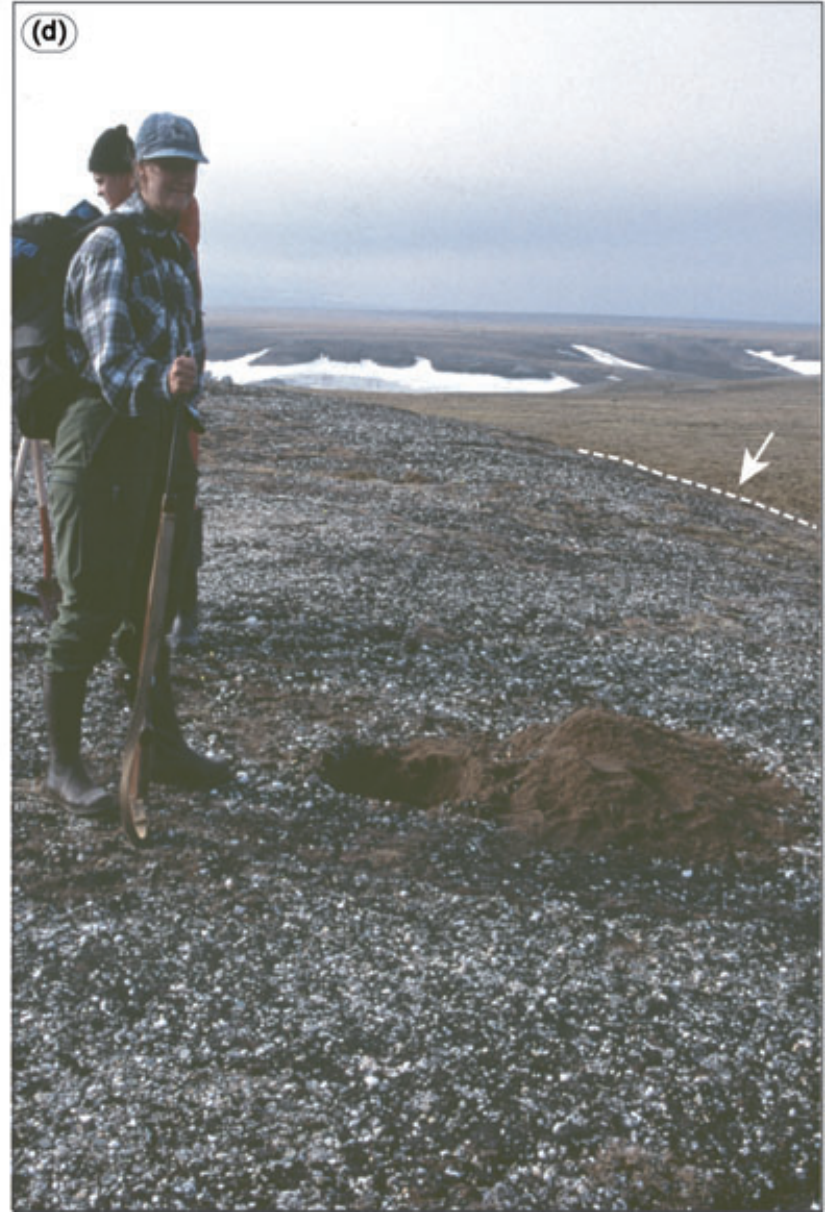

Fig. 3 (a) The meandering Anjeliko River cutting into Cretaceous strata, draped by 1-4 m of Quaternary sediments. (b) The uppermost reaches of the Anjeliko River at ca. 60 m a.s.I., showing the flat coastal plain rising towards the Astrup Mountain in the background, with its plateau at $315 \mathrm{~m}$ a.s.I. (c) The staircase trenching of a Quaternary sediment succession at site Anjeliko River 4. (d) Beach terrace in unit-D marine sediments north-west of the Anjeliko River (Fig. 2b). The foot of the terrace (ca. $60 \mathrm{~m}$ a.s.I.) is indicated by the arrow and dashed line.

valley (Fig. 2a), which were overlain by glacial and glaciofluvial sediments. These sediments were in turn observed to be overlain by a younger marine unit (not dated but tied to the "Karginsk" interstadial) at altitudes between 0 and $50 \mathrm{~m}$ a.s.l.

A short reconnaissance during the Swedish-Russian Tundra Ecology 1994 expedition in the Tessema Bay area, some 50-60 km south-west of Cape Chelyuskin (Fig. 2a), revealed widespread sandy deposits, rich in marine molluscs (Hjort, pers. comm.). The aerial photographic interpretation of the area north of the Tessema River indicated high (20-30 $\mathrm{m}$ a.s.l.), steep and frequent exposures of presumably Quaternary sediments along all major river valleys. Based on this, we primarily targeted the Anjeliko and Kratnaya river valleys (Fig. 2a), situated west of Astrup Mountain, in our 1999 field campaign to the Chelyuskin Peninsula. Secondary to these river valleys was a reconnaissance to the Serebryanka River valley, situated east of Astrup Mountain (Fig. 2a).

The initial reconnaissance in the Anjeliko River valley in fact showed that most river sections are cut into Cretaceous sediments (Figs. 3a, 4a), usually consisting of coarse- to medium-grained and massive to vaguely stratified sandstone. The sandstone forms weakly lithified units, interbedded with more lithified, 1-2-m-thick units. The latter units are especially rich in marine molluscs, among these Ostrea ssp., with diameters up to $15 \mathrm{~cm}$, belemnites, ammonites, fossil wood and coal lenses. In places, the Cretaceous sediments also form the ground surface adjacent to the river sections, but more commonly there is a cover of quite thin but unexposed Quaternary sediments (not shown in section), which are usually sand and often have a lag of mollusc shells on the surface. Small tributary streams often terminate further 


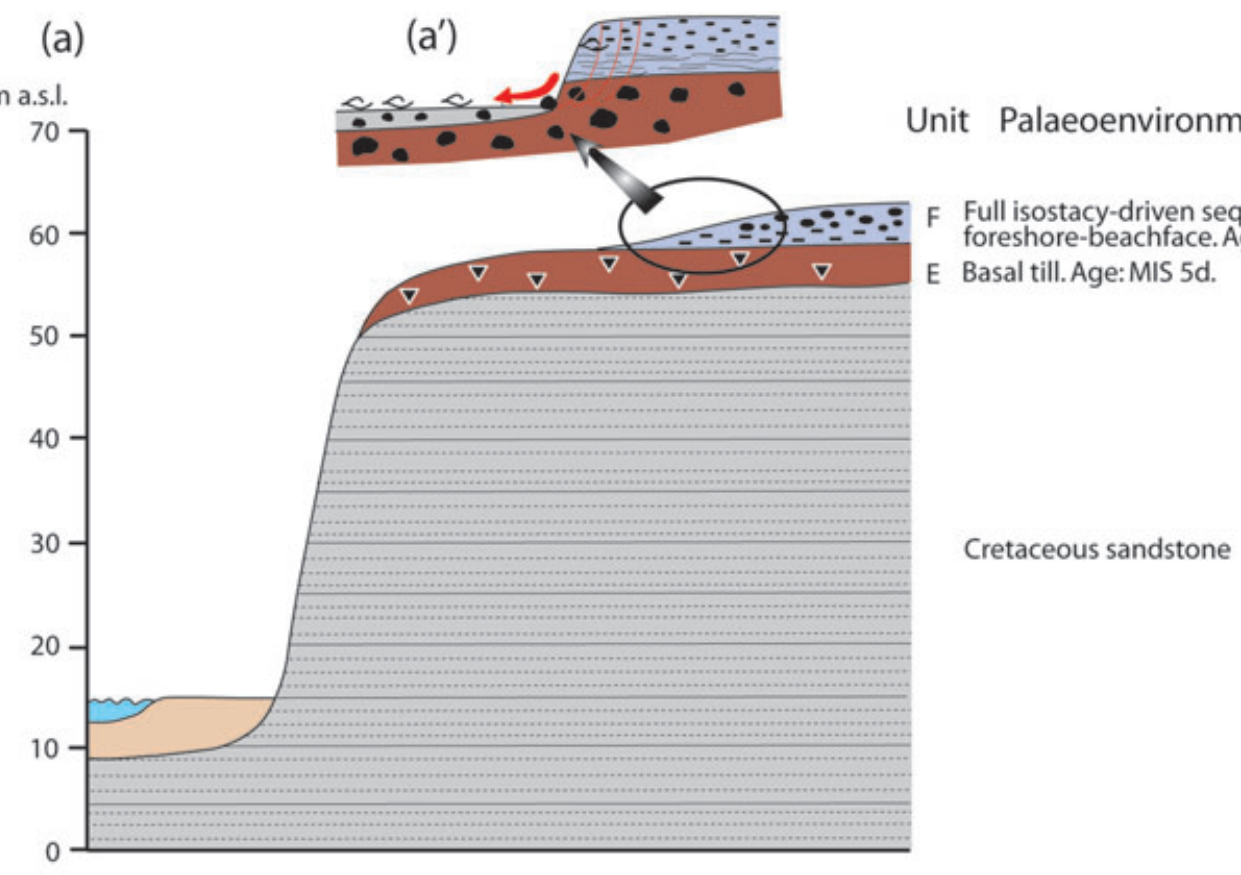

(b)

m a.s.l.

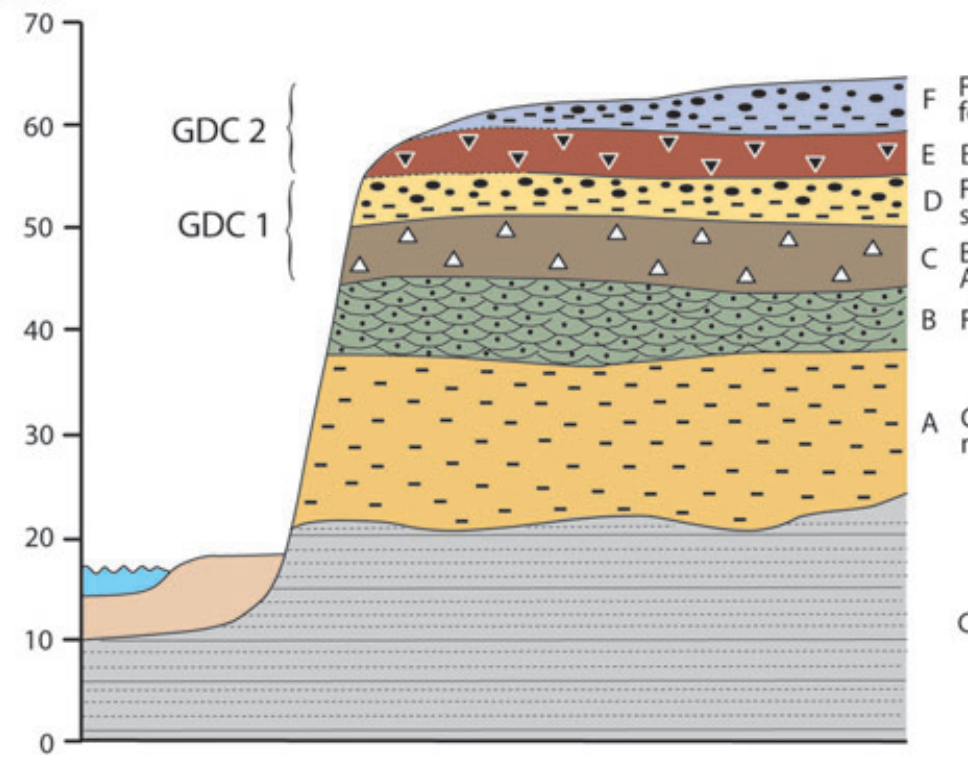

Full isostacy-driven sequence: marine-shorefaceforeshore-beachface. Age: MIS $5 \mathrm{~d} / 5 \mathrm{c}$ transition.

E Basal till. Age:MIS 5d.

Full isostacy-driven sequence: glaciomarine-marineshoreface-foreshore-beachface. Age: MIS6/5e transition.

C Basal till. Ice-flow towards KaraSea shelf. Age: MIS 6.

Fluvial braid-plain. Age: pre-MIS 6.

Glaciomarine-marine sediments with subarctic mollusc fauna. Age: > 1.8 My.

Cretaceous sandstone

Fig. 4 Principal stratigraphy of Quaternary deposits on the north-western coast of the Chelyuskin Peninsula, showing the inferred relationship between the Cretaceous sedimentary bedrock topography and the identified glacial tills, and fluvial and marine deposits. The Quaternary sediments usually just form a thin cover, as shown in (a). However, in some places thick and complex successions of post-Cretaceous sediments fill in the palaeovalley depressions, as indicated in (b). All post-Cretaceous sediments are divided into six lithostratigraphic/sedimentary units (A-F), and their interpreted depositional environments and ages are indicated. GDC1 and GDC2 denote the first and second full glacial/deglacial cycles, as indicated from the sediment successions.

away from the river valleys in areas with a series of slump scars, driven by back-wasting into the permafrost (Fig. 4a) and revealing more of the architecture of the Quaternary cover. Below the active back wall, i.e., in the frontal accumulation area, there is redeposited silt and silty diamict, often with large erratics and an abundance of redeposited marine mollusc shells. It is uncertain whether this back-wall diamict is exposed in situ, as the 
lower part of the back walls are frozen. It is thus often not possible to conclude whether it is redeposited sediment or not. The upper back-wall parts reveal marine deposits, ranging from silt to gravel, that are often in coarsening upward successions, and which are usually rich in molluscs. These sediments are the source of the redeposited shells further downslope.

According to our reconnaissance work, the Cretaceous sediments (sketched in Fig. 4a) are the totally predominating deposits up to $4-6 \mathrm{~km}$ inland from the present coast. However, further inland there are 200-400-m-long stretches along the present-day river valleys that contain younger sediments. These are exposed more or less from the river floor to the top of the valley (Fig. 4b), and are bounded further up- and down-valley by rising surfaces of the Cretaceous deposits. Our interpretation is that these sediments represent palaeovalley or palaeobasin fills into a post-Cretaceous topography. As will be demonstrated in the site descriptions, these fills consist of a lowermost marine sequence (unit A) of pre-Quaternary age, followed by an intermediate succession of fluvial (unit B), glacial (unit C) and marine (unit D) sediments, all of Quaternary age (Fig. 4b). Furthermore, the topmost draping sediments consist of a younger succession of glacial (unit E) and marine (unit F) sediments (Fig. 4). This suggested total stratigraphy could not be confirmed from just one section with all units occurring in stratigraphic superposition (e.g., as in the Ozernaya River valley on October Revolution Island, Severnaya Zemlya; Möller et al. 2006), but has been pieced together from stratigraphic, sedimentologic and chronological correlations.

\section{Methods}

Fieldwork was conducted in the Cape Chelyuskin area in July-August 1999. Geomorphic observations were combined with sedimentological assessment, glaciotectonic analyses and geochronological investigations.

\section{Mapping}

Aerial photographs and 1:100 000 topographic maps were used to map marine terrace surfaces, raised beaches and large sediment exposures over broad areas of Cape Chelyuskin). Image-based interpretations were refined in the field with a barometric altimeter $( \pm 2 \mathrm{~m})$, with reference to river-base levels and other points taken from topographic maps.

\section{Stratigraphic analyses}

We concentrated on laterally extensive sections and targeted geochronological sampling. The sections were dug out in a staircase manner (Fig. 3c), and were logged
Table 1 Lithofacies codes (first, second and third order code system) and their description, as used in this work (based on Eyles et al. 1983).

\begin{tabular}{|c|c|}
\hline $\begin{array}{l}\text { Lithofacies } \\
\text { code: }\end{array}$ & $\begin{array}{l}\text { Lithofacies type description: grain size, grain support } \\
\text { system, internal structures }\end{array}$ \\
\hline $\mathrm{D}(\mathrm{G} / \mathrm{S} / \mathrm{Si} / \mathrm{C})$ & $\begin{array}{l}\text { Diamicton, gravelly, sandy, silty or clayey. One or more } \\
\text { grain-size code letters within brackets }\end{array}$ \\
\hline $\mathrm{D}$ () $\mathrm{mm}$ & Diamicton, matrix-supported, massive \\
\hline $\mathrm{D}() \mathrm{ms}$ & Diamicton, matrix-supported, stratified \\
\hline $\mathrm{D}($ ) $\mathrm{mm} / \mathrm{ms}(\mathrm{s})$ & Diamicton, . . . , sheared \\
\hline $\mathrm{D}($ ) ms(a) & Diamicton, ... . attenuated \\
\hline $\mathrm{CO}-$ & Cobbles, as below \\
\hline $\mathrm{D}($ ) mm(ng) & Diamicton, matrix-supported, massive, normally graded \\
\hline $\mathrm{D}($ ) mm(ig) & Diamicton, matrix-supported, massive, inversely graded \\
\hline $\mathrm{D}$ ( ) mm (ing) & $\begin{array}{l}\text { Diamicton, matrix-supported, massive, inverse to } \\
\text { normally graded }\end{array}$ \\
\hline Gmm & Gravel, matrix-supported, massive \\
\hline Gcm & Gravel, clast-supported, massive \\
\hline $\begin{array}{r}\mathrm{Gcm}(\mathrm{ng}) \\
-(\mathrm{cng}) \\
-(\mathrm{mng})\end{array}$ & $\begin{array}{l}\text { Gravel, clast-supported,massive, normally graded; clast } \\
\text { normal grading, matrix normal grading }\end{array}$ \\
\hline Gcm(ig) & Gravel, clast-supported, massive, inversely graded \\
\hline $\mathrm{Sm}$ & Sand, massive \\
\hline $\operatorname{Sm}(\mathrm{b})$ & Sand, massive (burrows, bioturbated) \\
\hline Sm(ng) & Sand, massive, normally graded \\
\hline Sm(ig) & Sand, inversely graded \\
\hline Spp & Sand, planar parallel-laminated \\
\hline Spc & Sand, planar cross-laminated \\
\hline Stc & Sand, trough cross-laminated \\
\hline $\mathrm{Sr}$ & Sand, ripple-laminated \\
\hline SI(def) & Sand, laminated, deformed \\
\hline Sim & Silt, massive \\
\hline Sil & Silt, laminated \\
\hline $\mathrm{Cl}$ & Clay, laminated \\
\hline $\mathrm{Cm}$ & Clay, massive \\
\hline $\mathrm{Cm}(\mathrm{dr})$ & Clay, massive (dropstones) \\
\hline
\end{tabular}

mostly at 1 : 10 scale using standardized lithofacies codes (Table 1). Fabric analyses in diamict beds were based on 25 clasts, the longest axes of which were $3-10 \mathrm{~cm}$, and which had $a / b$-axis ratios of $>1.5$. All structural data were statistically evaluated, the fabric data according to the eigenvalues method (Mark 1973), and were graphically manipulated in STEREONET for Windows.

\section{Foraminiferal analyses}

Samples from five sections were processed at the University of Aarhus using 100-300 g of dry sediment washed through sieves with mesh diameters of 63, 100 and $1000 \mu \mathrm{m}$ (see Feyling-Hanssen 1983). Foraminifera were concentrated using a heavy liquid $\left(1.8 \mathrm{~g} \mathrm{~cm}^{-3}\right)$. The entire $100-1000-\mu \mathrm{m}$ fraction of all samples was analysed for its foraminiferal content, but many samples proved barren, and in no samples was it possible to identify more than 300 specimens (Table 2 ). The $63-100-\mu \mathrm{m}$ fractions were checked for additional species not present in the larger 
Table 2 Foraminiferal analyses of unit A from Anjeliko River, and of deposits from the Serebryanka River area. Only samples containing foraminifera are shown. Data are shown as actual foraminiferal counts per sample (in 100 or $300 \mathrm{~g}$ of sediment). Species names, including authorities, are given in alphabetical order.

\begin{tabular}{|c|c|c|c|c|c|c|c|c|c|}
\hline \multirow{2}{*}{$\frac{\text { Study sites }}{\text { Sample no }}$} & \multicolumn{5}{|c|}{ Anjeliko River 3 (unit A) } & \multicolumn{4}{|c|}{ Serebryanka River 3} \\
\hline & 24 & 23 & 22 & 8 & 7 & 4 & 3 & 2 & 1 \\
\hline Altitude (m.a.s.l.) & 39.0 & 39.5 & 40.0 & 47.2 & 47.5 & 61.5 & 62.3 & 62.9 & 63.3 \\
\hline Sample size (gram) & 300 & 300 & 100 & 100 & 300 & 100 & 100 & 100 & 100 \\
\hline \multicolumn{10}{|l|}{ Calcareous foraminifera } \\
\hline Astrononion gallowayi Loeblich \& Tappan, 1953 & & & & & & 1 & & & \\
\hline Buccella frigida (Cushman, 1922) & & & & & & & & 1 & 1 \\
\hline Buccella hannai arctica Voloshinova, 1960 & 5 & 3 & & & & 1 & 1 & 1 & \\
\hline Buccella tenerimma (Brady, 1950) & & 1 & & & & & & & \\
\hline Cassidulina laevigata d'Orbigny, 1826 & 1 & & & & & & & 1 & \\
\hline Cassidulina reniforme Nørvang, 1945 & 1 & 4 & & & & 1 & & & 7 \\
\hline Cassidulina teretis (Tappan, 1951) & 22 & 11 & & & 2 & & & & \\
\hline Cibicides grossus ten Dam \& Reinhold, 1941 & 33 & 21 & & & 5 & 1 & & & \\
\hline Cibicides lobatulus (Walker \& Jacob, 1798) & 7 & 4 & & & 3 & 1 & & 1 & 5 \\
\hline Cibicides refulgens de Montfort, 1808 & 1 & & & & & & & & \\
\hline Cibicides cf. scaldisiensis ten Dam \& Reinhold, 1941 & & & & & & 1 & & & \\
\hline Elphidium albiumbilicatum (Weiss, 1954) & 9 & 10 & & & 1 & & & & 4 \\
\hline Elphidium asklundi Brotzen, 1943 & & & 1 & & & & 1 & 2 & \\
\hline Elphidium bartletti Cushman, 1933 & 3 & 1 & & & & & & & \\
\hline Elphidium excavatum (Terquem, 1876) & 33 & 20 & & & 9 & 7 & 2 & 4 & 11 \\
\hline Elphidium hallandense Brotzen, 1943 & 8 & 2 & & & & & 1 & 4 & \\
\hline Elphidium hughesi Cushman \& Grant, 1927 & 1 & & & & & & & & \\
\hline Elphidium incertum (Williamson, 1858) & 1 & & & & & & & & \\
\hline Elphidium tumidium (Gudina, 1969) & & & & & 5 & & & & \\
\hline Elphidium ustulatum Todd, 1957 & 1 & 1 & & & & & & & \\
\hline Epistominella nipponica Kuwano, 1967 & 1 & 2 & & & & & & & \\
\hline Epistominella takayangii Iwasa, 1955 & 14 & 5 & & & & & & 2 & \\
\hline Haynesina nivea (Lafrenz, 1963) & 3 & 1 & & & 1 & & & & \\
\hline Haynesina orbiculare (Brady, 1881) & 7 & 7 & & & 4 & & 1 & 6 & 1 \\
\hline Islandiella helenae Feyling-Hanssen \& Buzas, 1976 & 3 & 3 & & & & & & 3 & 1 \\
\hline Islandiella inflata (Gudina, 1966) & 1 & & & & 1 & & & & \\
\hline Islandiella islandica (Nørvang, 1945) & 1 & & & & & & & & \\
\hline Islandiella norcrossi (Cushman, 1933) & & & & & & 4 & 3 & & \\
\hline Melonis barleeanus (Williamson, 1858) & 1 & & & & & & & & \\
\hline Nonionella auricula Heron-Allen \& Earland, 1930 & & & & & & & & 1 & \\
\hline Nononellina labradorica (Dawson, 1860) & & 1 & & & & & & & \\
\hline Quinqueloculina seminulum (Linné, 1758) & & & & 1 & & & & & \\
\hline Unilocular calcareous (4 species) & 2 & 3 & & & & & 1 & 1 & \\
\hline Nodosaridae (13 species) & 36 & 10 & & & & 1 & 1 & 1 & 4 \\
\hline Other calcareous foraminifera (4 species) & 4 & & & & & & & 1 & \\
\hline \multicolumn{10}{|l|}{ Agglutinated foraminifera } \\
\hline Spiroplectammina deperdita (d'Orbigny, 1846) & 1 & & & & & & & & \\
\hline Unidentified agglutinated & 2 & 2 & & & & & & & 1 \\
\hline Total counts & 202 & 112 & 1 & 1 & 31 & 18 & 11 & 29 & 35 \\
\hline No. species & 43 & 27 & 1 & 1 & 9 & 9 & 8 & 14 & 10 \\
\hline
\end{tabular}

fraction: none were found. The foraminiferal specimens found were generally well preserved: 56 species of benthic and no planktonic foraminifera were present in the material (Table 2).

\section{Geochronology}

Three dating methods were employed: accelerator mass spectrometer radiocarbon $\left(\right.$ AMS $\left.{ }^{14} \mathrm{C}\right)$, electron spin reso- nance (ESR) and optically stimulated luminescence (OSL). AMS and ESR were used to date molluscs and OSL was used to date sediments.

A total of five AMS ${ }^{14} \mathrm{C}$ ages were determined at the Lund University Radiocarbon Dating Laboratory (Table 3). The pre-treatment of mollusc shells included leaching to ca. $70 \%$ of their original mass. As all datings indicated an infinite ${ }^{14} \mathrm{C}$ age, no marine reservoir correction was necessary. 
Table 3 Accelerator mass spectrometry (AMS) ${ }^{14} \mathrm{C}$ ages from the investigated sites. For locations, see Figs. 2 and 9.

\begin{tabular}{|c|c|c|c|c|c|c|}
\hline Sites & Sample no. & Dated material & Sed. unit & Sample m a..s.l. & Lab no. & Conv. ${ }^{14} \mathrm{C}$ age \\
\hline Anjeliko River 4 & AR1:2 & Hiatella arctica & $D$ & 58.3 & LuA-4853 & $>40000$ \\
\hline Bolotniy River 1 & BR1:1 & Hiatella arctica & $D$ & 45.7 & LuA-4854 & $>40000$ \\
\hline Bolotniy River 1 & BR1:2 & Astarte borealis & $\mathrm{D}$ & 46.5 & LuA-4855 & $>40000$ \\
\hline Kratnaya River 2 & $\mathrm{KR} 2: 1$ & Astarte borealis & D & 38.1 & LuA-4851 & $>40000$ \\
\hline Anjeliko River 1 & AR1:2 & Hiatella arctica & $\mathrm{F}$ & 64.8 & LuA-4852 & $>40000$ \\
\hline
\end{tabular}

Table 4 Electron spin resonance (ESR) ages from the investigated sites. For locations, see Figs. 2 and $9 . U_{\text {in }}$ is the uranium content in shells; $U$, Th and $\mathrm{K}$ are the uranium, thorium and potassium content in sediments. $D_{\Sigma}$ is the total dose rate; $P_{s}$ is the palaeodose.

\begin{tabular}{|c|c|c|c|c|c|c|c|c|c|c|c|c|}
\hline Site & Sample no. & Lab no. & Dated mollusc & $\begin{array}{l}\text { Sed. } \\
\text { unit }\end{array}$ & $m$ a.s.l. & $\begin{array}{l}U_{\text {in }} \\
\text { (ppm) }\end{array}$ & $\begin{array}{l}\text { U } \\
\text { (ppm) }\end{array}$ & $\begin{array}{l}\text { Th } \\
\text { (ppm) }\end{array}$ & $\mathrm{K}(\%)$ & $\begin{array}{l}D_{\Sigma} \\
\left(\mu G y a^{-1}\right)\end{array}$ & $P_{\mathrm{s}}(\mathrm{Gy})$ & ESR age (Ky) \\
\hline Anjeliko River 3 & AR3:25 & $290-060$ & Astarte borealis & A & 39.5 & 0.75 & 1.50 & 7.15 & 1.79 & 2079 & 1444.78 & $715.0 \pm 46.8$ \\
\hline Anjeliko River 4 & AR4:1 & $291-060$ & Hiatella arctica & D & 58.3 & 1.70 & 0.85 & 3.23 & 1.37 & 1739 & 248.00 & $143.4 \pm 10.8$ \\
\hline Bolotniy River 1 & BR1:1 & $294-060$ & Mya truncata & D & 45.7 & 0.83 & 0.43 & 2.00 & 1.31 & 1271 & 197.34 & $156.3 \pm 10.8$ \\
\hline Bolotniy River 1 & BR1:2 & $295-060$ & Astarte borealis & D & 46.5 & 1.10 & 0.72 & 1.98 & 1.61 & 1440 & 207.61 & $145.1 \pm 10.2$ \\
\hline Kratnaya River 1 & KR1:1 & $2978-060$ & Hiatella arctica & D & 41.9 & 2.80 & 0.77 & 3.15 & 1.16 & 1931 & 230.03 & $118.4 \pm 7.1$ \\
\hline Kratnaya River 1 & KR1:2 & $299-060$ & Hiatella arctica & D & 41.8 & 1.50 & 0.71 & 4.07 & 1.17 & 1633 & 230.24 & $141.9 \pm 10.2$ \\
\hline Kratnaya River 2 & $\mathrm{KR} 2: 1$ & $301-060$ & Astarte borealis & D & 38.1 & 1.60 & 1.30 & 4.12 & 1.47 & 1858 & 218.64 & $118.2 \pm 8.3$ \\
\hline Kratnaya River 2 & $\mathrm{KR} 2: 3$ & $302-060$ & Hiatella arctica & D & 37.2 & 2.30 & 1.50 & 6.43 & 1.23 & 2095 & 264.23 & $126.8 \pm 9.0$ \\
\hline Kratnaya River 3 & KR3:1 & $302-060$ & Hiatella arctica & D & 33.8 & 0.75 & 1.34 & 5.33 & 1.41 & 1695 & 187.42 & $111.1 \pm 7.7$ \\
\hline Kratnaya River 3 & KR3:3 & $304-060$ & Hiatella arctica & D & 32.3 & 1.40 & 0.80 & 3.69 & 1.45 & 1503 & 184.99 & $123.6 \pm 9.0$ \\
\hline Anjeliko River 1 & AR1:1 & $288-060$ & Hiatella arctica & $\mathrm{F}$ & 65.5 & 0.71 & 1.03 & 4.04 & 1.30 & 1403 & 120.58 & $86.3 \pm 6.2$ \\
\hline Anjeliko River 1 & AR1:2 & $289-060$ & Hiatella arctica & $\mathrm{F}$ & 64.8 & 1.50 & 1.09 & 4.46 & 1.35 & 1579 & 135.93 & $86.4 \pm 6.7$ \\
\hline Serebryanka River 1 & SER1:1 & $305-060$ & Hiatella arctica & $\mathrm{F}$ & 76.0 & 5.80 & 1.41 & 6.41 & 1.55 & 3142 & 248.99 & $79.5 \pm 6.0$ \\
\hline Serebryanka River 2 & SER2:1 & $306-060$ & Astarte borealis & $\mathrm{F}$ & 75.2 & 1.20 & 1.33 & 5.91 & 1.47 & 2191 & 202.91 & $93.0 \pm 6.6$ \\
\hline
\end{tabular}

Table 5 Optically stimulated luminescence (OSL) ages from the investigated sites. For locations, see Figs. 2 and 9.

\begin{tabular}{lllllllllc}
\hline Site & Sample no. & Lab no. & Sed. unit & m a.s.l. & $n$ & w.c. \% & Equivalent dose (Gy) & Dose rate (Gy) & OSL age (Ky) \\
\hline Anjeliko River 3 & AR3:1 & 991035 & B & 50.8 & 21 & 3 & $237 \pm 19$ & 2.30 & $100 \pm 10$ \\
Anjeliko River 3 & AR3:3 & 991037 & B & 52.8 & 17 & 3 & $213 \pm 6$ & 12.27 & $110 \pm 7$ \\
Anjeliko River 3 & AR3:5 & 991039 & D & 58.4 & 15 & 2 & $129 \pm 3$ & 1.63 & $79 \pm 5$ \\
Anjeliko River 3 & AR3:6 & 991040 & D & 57.1 & 15 & 6 & $269 \pm 33$ & 1.90 & $135 \pm 18$ \\
Kratnaya River 1 & KR1:3 & 991027 & D & 42.8 & 23 & 7 & $230 \pm 22$ & 2.69 & $84 \pm 10$ \\
Kratnaya River 2 & KR2:5 & 991031 & D & 38.5 & 21 & 5 & $234 \pm 15$ & 2.29 & $100 \pm 9$ \\
\hline
\end{tabular}

The 14 ESR ages (Table 4) of marine molluscs were performed at the Research Laboratory for Quaternary Geochronology at Tallinn Technical University, Estonia. Unexposed shell samples were retrieved from within cleaned sections, followed by sampling of sediments enclosing the dated shell for measurements on background dose rates. Standard analytical procedures were used (Molodkov 1988; Molodkov et al. 1998).

A total of six OSL ages (Table 5) were determined at the Nordic Centre for Luminescence Research, Risø, Denmark. The single aliquot regenerative dose protocol, applied to quartz grains, was used to estimate the equivalent dose (Murray \& Wintle 2000). The samples were analysed for natural series radionuclide concentrations in the laboratory, using high-resolution gamma spectrometry (Murray et al. 1987). These concentrations were converted into dose rates using the convention factors listed by Olley et al. (1996).

\section{Study sites}

\section{Anjeliko River area}

Post-Cretaceous sediments, lying as palaeobasin/valley fills, were documented from three sites along the Anjeliko River valley (AR2, $77^{\circ} 22^{\prime} \mathrm{N} 102^{\circ} 44^{\prime} \mathrm{E}$; AR3, $77^{\circ} 21^{\prime} \mathrm{N}$ $102^{\circ} 43.5^{\prime} \mathrm{E}$; AR4, $77^{\circ} 21.5^{\prime} \mathrm{N} 102^{\circ} 41^{\prime} \mathrm{E}$; Fig. $\left.2 \mathrm{~b}\right)$, and at one site along the nearby Bolotniy River (BR1, $77^{\circ} 23.5^{\prime} \mathrm{N}$ $102^{\circ} 39.7^{\prime} \mathrm{E}$; Fig. 2a). The most complete section is AR3: starting just above the present river bed at $38.8 \mathrm{~m}$ a.s.l and ending at $58.5 \mathrm{~m}$ a.s.l., and exposing $19.7 \mathrm{~m}$ of sediment. The top of the section is an erosional surface with 
a bouldery cobble lag, and at least $2-3 \mathrm{~m}$ of sediment is missing when compared with the topmost altitude of the plateau between sites AR3 and AR4 (Fig. 2b). The sediments exposed at these sites are divided into four units (A-D, Fig. 5).

One additional site, ARl (ARl: $77^{\circ} 22^{\prime} \mathrm{N} 102^{\circ} 43.8^{\prime} \mathrm{E}$; Fig. 2b), is found near the top of a plateau surface reaching ca. $68 \mathrm{~m}$ a.s.l. Here, two additional units, E and $\mathrm{F}$ (Fig. 5), are exposed in a series of back-wasting scars. Raised marine sediments (unit F) covering this plateau are delimited in the north-west by a pronounced escarpment, which is $2-3 \mathrm{~m}$ high, and which has a base at ca. $60 \mathrm{~m}$ a.s.l., and can be easily followed, both in the terrain and on aerial photographs, at a constant altitude for ca. $5 \mathrm{~km}$ (Figs. 2b, 3d). We interpret this escarpment as a marine regressive shoreline, i.e., it does not indicate the highest position of the marine sediments into which it cuts. The escarpment and the small terrace below consist of gravelly sand. The latter has a high frequency of small crystalline boulders, a residual of the marine abrasion into units E and F. Sandy deposits south of the Anjeliko River could be followed as quite thin deposits up to altitudes of ca. $80 \mathrm{~m}$ a.s.l., but no sections were available.

Unit A: description. Unit A is only exposed at site AR3 (Fig. 5), with a minimum thickness of $9.5 \mathrm{~m}$. The succession starts with massive, slightly sandy silt, with an abundance of out-sized floating clasts $(2-6 \mathrm{~cm})$, intrabedded by $0.5-1-\mathrm{cm}$-thick sand beds (Fig. 6d). A few shell fragments also occur. With a sharp boundary, the sequence continues with massive clayey silt, changing further upwards into a weakly laminated clay. There are abundant out-sized clasts (maximum particle size [MPS] $10 \mathrm{~cm}$ ) and a few sand intrabeds in the lower ca. $1 \mathrm{~m}$ of the unit, both of which become less frequent higher up, and in fact almost disappear near the top of the unit. The lower part carries abundant in situ fossil molluscs (Astarte borealis), becoming less frequent to absent upwards.

Foraminifera were analysed for every $0.5 \mathrm{~m}$ through the section (17 samples). Many of the samples proved barren, and a true foraminiferal fauna was only found in two samples at 39.0 and $39.5 \mathrm{~m}$ a.s.l., whereas an assemblage of fewer specimens could be identified at $47.5 \mathrm{~m}$ a.s.l. (Table 2). The three samples revealed a diverse assemblage with 52 different species in total, dominated by Elphidium excavatum, Cibicides grossus and Cassidulina teretis, which is similar to Cassidulina cf. teretis sensu Feyling-Hanssen et al. (1983). Other species include Epistominella takayanagii, Elphidium albiumbilicatum, Elphidium hallandense, Cibicides lobatulus, Haynesina orbiculare, Buccella hannai arctica and several species of Nodosaridea. Also notable is the presence of a few
Elphidium tumidum, Elphidium hughesi, Epistominella nipponica and Spiroplectammina deperdita.

A single mollusc sample from the lower part of the sequence yielded an ESR age of $715 \mathrm{Ky}$ (Table 4).

Unit A: interpretation. The lowermost sandy silt, with abundant floating out-sized clasts, suggests an offshore, possibly glaciomarine environment dominated by suspension settling. The frequently occurring intrabedded sands represent distal parts of turbidites, whereas the floating clasts are interpreted as ice-rafted debris (IRD). The upward decrease in grain size and lower frequency of IRD suggests a full offshore marine environment. A marine environment is also supported by the occurrence of $A$. borealis, and it is therefore peculiar that most samples for foraminiferal analysis show up as barren. We suspect that this is because of dissolution; also, mollusc shells are very hard to retrieve from the sediment in identifiable pieces in certain horizons. Although the only ESR dating points towards a Middle to Early Pleistocene age, the foraminiferal assemblage indicates a significantly older age. $C$. grossus is known from pre-Pleistocene deposits from shelf regions in the North Atlantic and circum-Arctic regions. In shelf regions of Arctic Canada and East Greenland, it is believed to have become extinct at about 2.3-2.5 Mya (Feyling-Hanssen 1980; McNeil 1990; Fyles et al. 1998). In much of the North Sea its last common occurrence was at that time (Knudsen \& Asbjörnsdóttir 1991; Seidenkrantz 1992; Pedersen 1995), although it may have survived until the end of the Gelacian (1.8 Mya) in the deeper waters of the northern North Sea, and off the coast of Norway (King 1989; Eidvin et al. 1999; Eidvin \& Nagy 1999). C. teretis (not Cassidulina neoteretis Seidenkrantz, 1995) became less common after 2.0-2.3 Mya, and presumably became extinct about 0.7 Mya, just after the Bruhnes/Matuyama boundary (Seidenkrantz 1995). Other species known from Pliocene deposits include $S$. deperdita, E. nipponica and E. hughesi (Cushman \& Grant 1927: pl. 7-8; ten Dam \& Reinhold 1941; van Voorthuysen 1958; Doppert 1980). All this taken together indicate that unit A was presumably deposited prior to 2.3-2.5 Mya, although a later age (>1.8 My) cannot be ruled out.

Unit B: description. Unit B is exposed in sections AR2, AR3 and AR4 (Fig. 5), at AR4 with a thickness of $>7 \mathrm{~m}$. The lower contact to unit A is erosive at site AR3, continuing with interbedded sets of planar parallel-laminated and trough cross-laminated medium to coarse sand. At AR4, the succession is totally dominated by trough crosslaminated sand with bed thicknesses of 20-50 cm. Some beds are rich in coal intraclasts, 5-10 cm long (Fig. 6c), and some beds also reveal dissolved coal, deposited in lamina paralleling the internal cross lamination of the 


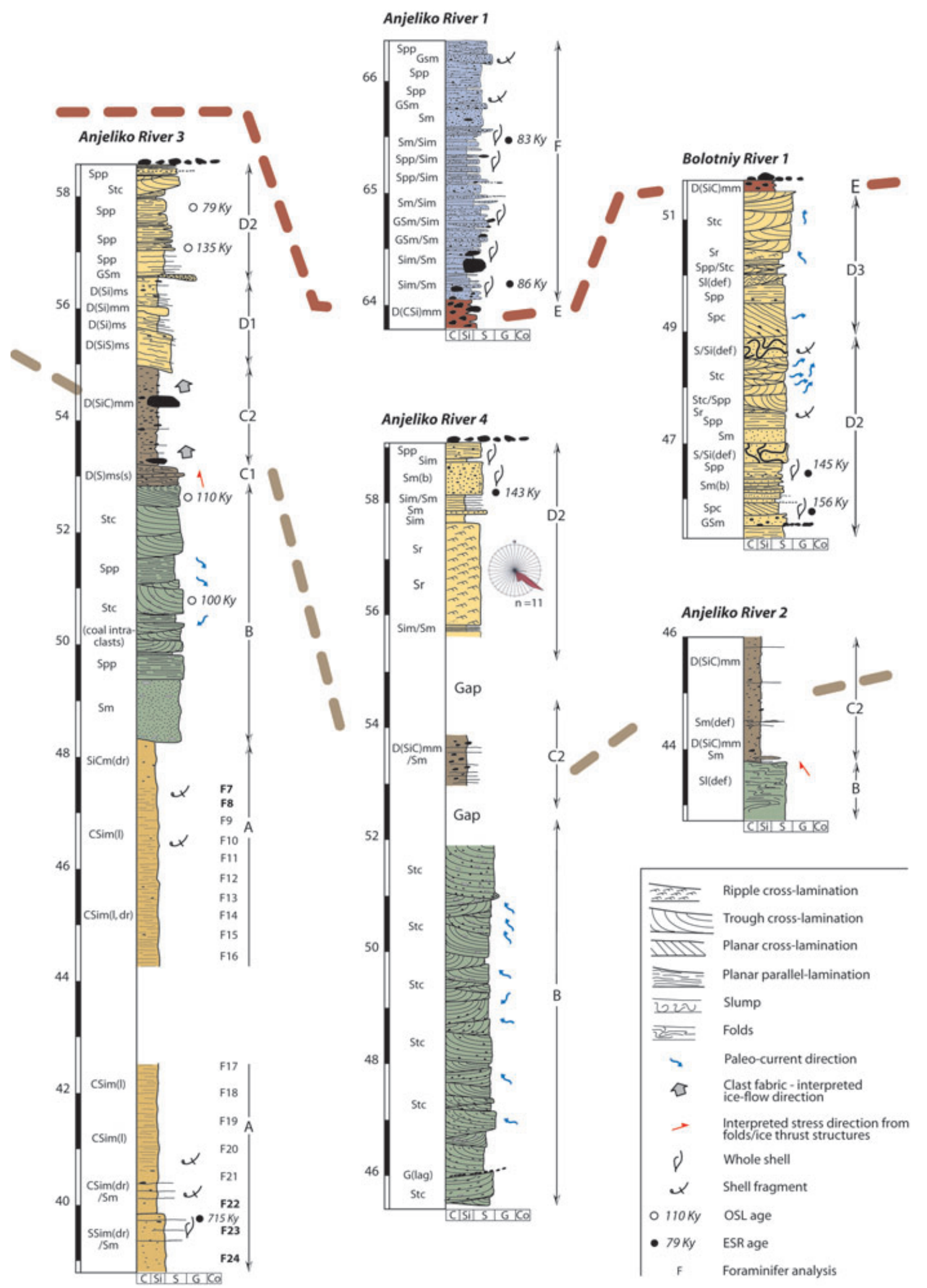

Fig. 5 Stratigraphic logs for sites along the Anjeliko and Bolotniy rivers (see Fig. $2 b$ for locations). The locations of samples containing foraminifera are marked with a boldface "F" (the species occurring are shown in Table 2). Note that the AR1 log is drawn in double-height scale. Colour codes for the units are the same as for Fig. 4. 
sand. Unidentifiable shell fragments occur at a low frequency thoughout the unit. Palaeoflow directions, as inferred from measurements on cross-laminated sets, are towards an eastern sector.

Two OSL samples taken from site AR3 provide ages of $110 \pm 7$ and $100 \pm 10 \mathrm{Ky}$ (Table 5). As will be shown later, these ages are too young compared with those retrieved from stratigraphically higher lying units.

Unit B: interpretation. The mollusc-free sediments indicate deposition in a subaerial environment, and the dominantly trough cross-laminated beds/bedsets suggest a fluvial within-channel braid-plain deposition. The shell fragments are considered to be erosional remnants from older marine deposits, and the abundant coal intraclasts are believed to be reworked from the Cretaceous strata. Because of the stratigraphic position of unit B, the OSL ages (110-100 Ky) are considered to be erroneous, and only indicate a minimum age.

Unit C: description. Unit $\mathrm{C}$ is a compact, matrixsupported, clast-rich silty clayey diamict, exposed in sections AR2, AR3 and AR4 (Fig. 5). Both the upper and lower contacts are only exposed in section AR3, where the diamict also shows the most diverse appearance over its $2.2-\mathrm{m}$ thickness. The contact with underlying unit B sand at site AR3 is sharp, and is marked by small-scale drag folds down into the sand (ca. $0.1 \mathrm{~m}$ ), whereas larger scale folding could be detected down to ca. $0.7 \mathrm{~m}$ below the contact at site AR2. The diamict above this contact can be divided into two subunits, with the lower subunit ( $\mathrm{Cl}$; ca. $0.4 \mathrm{~m}$ thick) characterized by a more sandy matrix and a stratified appearance, resulting from the frequent occurrence of thin sand intrabeds and intraclasts. In some places the latter form clasts that are more rounded at one end, and that taper off at the other end, and at other places sand intrabeds form un-rooted Z-shaped folds (Fig. 6b). The more horizontally continuous sand intrabeds also reveal small-scale folds, as well as pinch-and-swell structures. The measured fold axes strike at about NNE-SSW (Fig. 7).

Subunit C2 is a matrix-supported, massive diamict, which is rich in pebble- to boulder-sized clasts. The largest observed in the section is ca. $1 \mathrm{~m}$ in diameter, although clast diameters of 10-20 cm are more common (Fig. 6b). A few sand intrabeds occur in the lowermost part of subunit C2, and small shell fragments occur sporadically throughout the unit. Two fabric analyses were carried out in the C2 diamict at site AR3, both revealing a statistically significant long-axis preferred orientation ( $S_{1}$ eigenvalues of ca. 0.7; Fig. 7). $V_{1}$-axis orientations (with azimuths towards $169^{\circ} / 2^{\circ}$ and $152^{\circ} / 16^{\circ}$ ) suggest a stress-transfer direction from the SSE.
Unit C: interpretation. The unit- $C$ diamict is interpreted as a subglacially deposited till. The intensely stratified lower part indicates incorporation of unit-B sediments into a deforming bed zone, with the incorporated sand clasts being sheared-out and/or folded. The shear banding and intermixing disappear upwards (subunit C2), indicating a cut-off from the underlying sediment source and a higher degree of homogenization of the deforming bed. The lower subunit can be classified as a type-A glaciotectonite or a type-B deformation till in the terminology of Benn \& Evans (1996), transforming upwards into a type-A deformation till. The lower bed contact and deformational structures beneath it suggest ductile non-penetrative deformation of the unit-B sediments, which in their upper part can be recognized as type-B glaciotectonite (Benn \& Evans 1996; Evans et al. 2006). The fabric shape and strength data are typical for data reported on deformation till (e.g., Evans et al. 2006), with moderate strain rates during deposition. The stress direction implied from the clast $a$-axis fabric conforms to that of measured fold axes, and all structural data taken together imply that ice movement during deposition of the unit-C diamict was roughly from the south-east.

Unit D: description. Unit D is exposed in sections AR3, AR4 and BRl, and can be divided into three subunits with specific facies expressions (Fig. 5). Subunit Dl is a 1.6-m-thick succession of interbedded sand and diamict, and is only encountered at site AR3 (Fig. 6a). It starts with an intrabedded set of fine to medium sand, with a bed inclination of ca. $5-10^{\circ}$ towards the east, that laterally changes to gravelly sand. Upwards is a sandy/silty and clast-rich diamict (MPS, $10 \mathrm{~cm}$ ), which, depending on the frequency of intrabedded sand beds, can be characterized as a stratified diamict (thin, very frequent sand intrabeds), or as a massive diamict with thin sand intrabeds. The internal stratification dips by ca. 5-10 $0^{\circ}$ towards the east.

The sequence continues into subunit D2, which is characterized by a coarsening upward succession of massive clay and silt, with thin sand beds, continuing into interbedded planar parallel-laminated sand and thin massive silt beds, and ending with more coarse-grained interbedded sets of trough cross-laminated and planar parallel-laminated sand (Fig. 6i and h). No molluscs were encountered within subunit D2 at the logged AR3 site, but a reconnaissance excavation a few hundred metres downstream in the same stratigraphic unit revealed a low-frequency occurrence of both Hiatella arctica and Mya truncata, as well as a high-frequency occurrence of mollusc shells on the eroded top surface of the subunit. At site AR4 the subunit is characterized by a thick basal coset of ripple-laminated sand, continuing into interbedded 

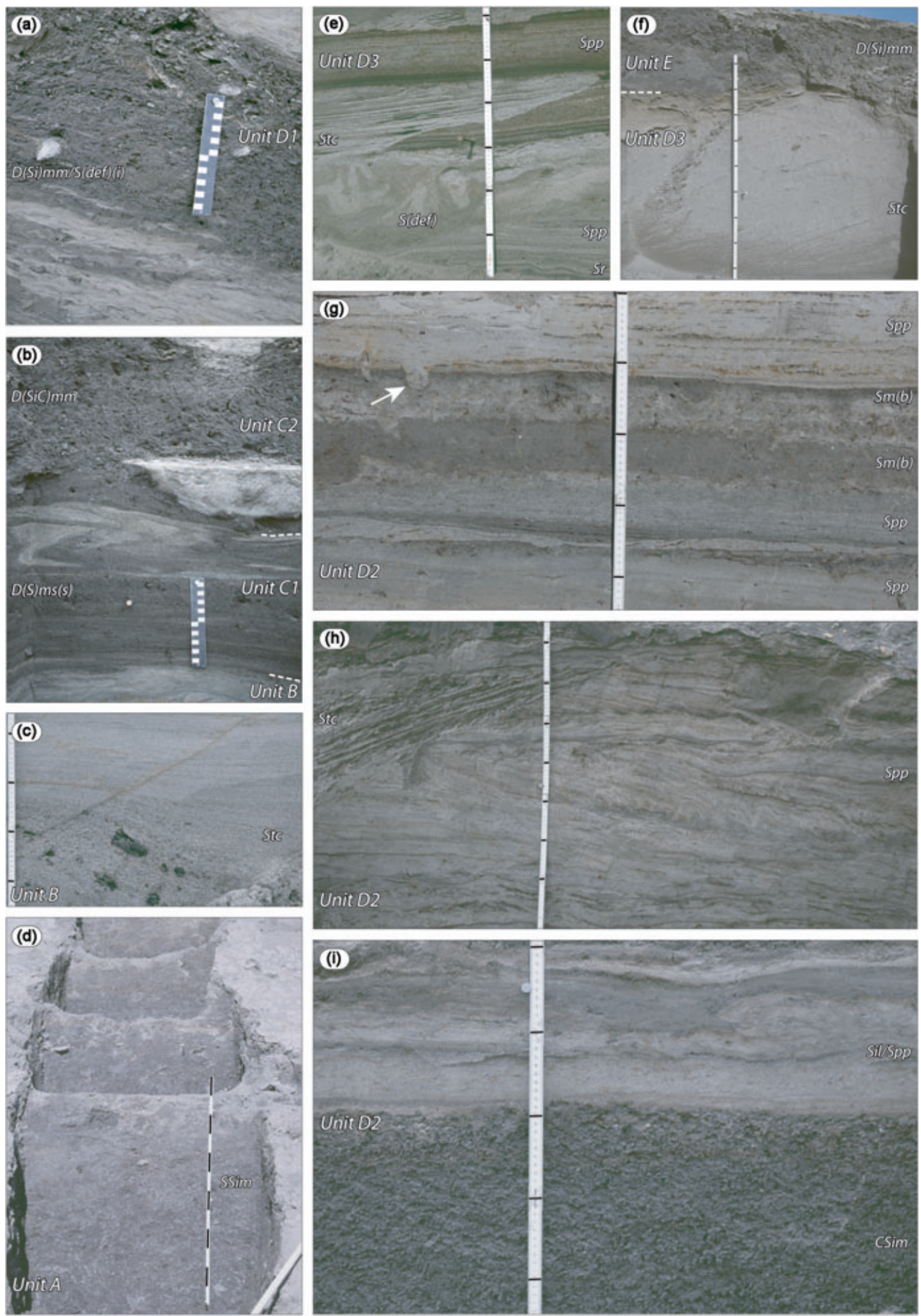
Fig. 6 (a) Unit-D1 marine sediments at AR3: interbedded glaciomarine debris-flow diamicts and sands. (b) Glaciotectonically folded unit-B fluvial sand, overlain by tectonically shear-laminated unit-C1 diamict, which is in turn overlain by massive unit-C2 diamict (site AR3). (c) Trough cross-laminated unit-B sand with coal intraclasts (site AR3). (d) Marine unit-A massive clayey silt, with the basal part rich in out-sized drop clasts (site AR3). (e) Interbedded trough cross-laminated and planar parallel-laminated sand, including slumped river bank sand (unit D3 fluvial plain sediments on top of marine units D1-D2; site at Bolotniy River). (f) Unit-E diamict on top of unit-D3 fluvial plain sediments (site BR1). (g) Marine unit-D2 planar parallel-laminated sand with frequent occurrences of bioturbated horizons. The sediments also host an abundant mollusc fauna (note the burrow trace indicated with an arrow). (h) Marine unit-D2 planar parallel-laminated sand, in the upper part truncated by cosets of trough cross-laminated sand (site AR3). (i) Marine unit-D2 interbedded clay, silt and sand (site AR3). Scale bars are marked with 10-cm intervals.

\section{Anjeliko River 3 (2), unit C2}

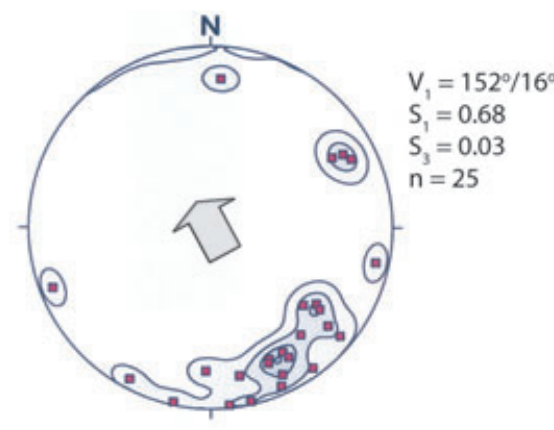

Anjeliko River 3 (1), unit C2

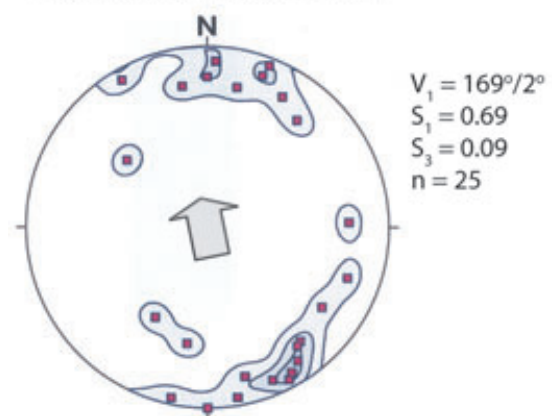

Kratnaya River 1, unit C2

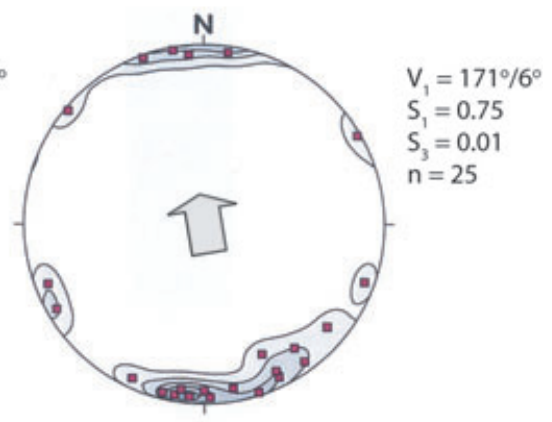

Kratnaya River 1, fold axes

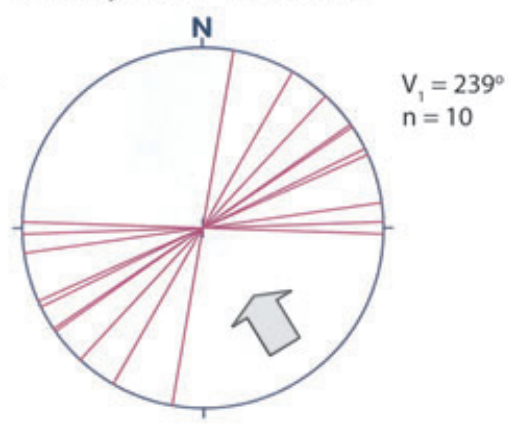

Fig. 7 Clast fabric and glaciotectonic data from the Anjeliko and Kratnaya river sites. Clast long axes are plotted as Schmidt equal-area, lower hemisphere projections. The largest eigenvector $\left(V_{1}\right)$ and normalized eigenvalues $\left(S_{1}\right.$ and $\left.S_{3}\right)$ are calculated according to the method described by Mark (1973). The axes directions (but not plunge) of measured glaciotectonic folds in unit-B sands and glaciotectonically laminated unit-C1 diamict are plotted on the same type of nets as above. The interpreted ice-flow direction and induced stress directions are shown by the large arrow in each plot.

\section{Anjeliko River 3, fold axes}

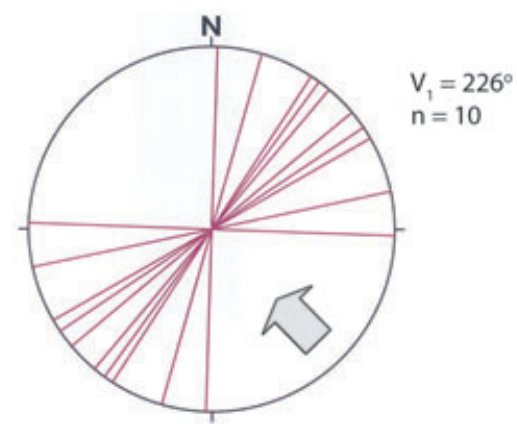

sand and silt, and massive sand, with abundant in situ molluscs ( $H$. arctica, M. truncata and $A$. borealis). Here, the top of the succession is an erosional low-angle slope, and ca. 4-5 $\mathrm{m}$ of sediment up to the plateau surface was inaccessible for logging. At site BR1 subunit D2 forms an interbedded sequence of predominantly planar parallel-laminated, planar cross-laminated and massive, bioturbated sand beds, all with an abundance of in situ molluscs (Fig. 6g). H. arctica, M. truncata and $A$. borealis are the dominating species, but a few specimens of Macoma calcarea and Serripes groenlandicus also occur. Also, a few Polydora ciliata and Natica borings in mollusc 
shells occur. Two mollusc samples from the subunit yielded infinite ${ }^{14} \mathrm{C}$ ages ( $>40 \mathrm{Ky}$; Table 3 ), and three ESR ages form a cluster at 143, 145 and $156 \mathrm{Ky}$ (Table 4), whereas two OSL datings are split in age: 79 and $135 \mathrm{Ky}$ (Table 5). Subunit D2 is draped by a lag of angular cobbles and boulders at sites AR3 and AR4, with boulder sizes not encountered within the unit D2 primary sediments.

Subunit D3 is only present at site BR1 (Fig. 5). Molluscs are absent, and the sequence is generally more coarsegrained and dominated by cosets of trough crosslaminated sand, each with individual 0.2-0.4-m-thick sets. Minor facies constituents are sets of ripple-laminated sand, often draped by silt, and planar parallel-laminated fine to medium sand, all frequently cut by $0.2-0.4-\mathrm{m}$ deep scour troughs, infilled by cross-laminated beds or contorted sand and silt (slump) (Fig. 6e). Palaeocurrent directions, as indicated from the cross strata, are predominantly towards the east.

Unit D: interpretation. The inclined sand beds and stratified diamict (unit Dl) are interpreted as sediment gravity flow deposits. Together with the high frequency of out-sized floating clasts, these deposits suggest a glaciomarine deglacial environment. The upward change into interlaminated, mollusc-rich silts and sands, and eventually into thick cosets of ripple-laminated sand, massive and planar parallel-laminated sands and gravelly sand (subunit D2), suggest a transition from offshore to shoreface and eventually foreshore depositional environments. This indicates a full isostacy-driven regressional sediment sequence. The dominating mollusc assemblage is a typical High Arctic community (Funder, pers. comm. 2007).

The vertically stacked sequence of trough crosslaminated sands, with minor occurrences of ripplelaminated and planar parallel-laminated sand at Bolotniy River (unit D3), suggests within-channel 3D bar migration in a braided river setting. The slumped sediment structures indicate frequent bar margin failure. The Bolotniy River section thus shows a transition from unit-D2 shoreface sediments into a subaerial depositional environment (unit D3), probably representing a prograding delta plain at a river mouth.

Unit E: description. Unquestionable stratigraphic evidence of a till younger than the unit- $\mathrm{C}$ diamict is only found in the Bolotniy River section (BR1; Figs. 5, 6f). Here, the unit-D sediments are erosively cut, and the sharp upper boundary is overlain by a compact, matrixsupported and massive silty diamict, which is only $0.2-$ $0.3-\mathrm{m}$ thick. The largest clast size is just $10 \mathrm{~cm}$, but the adjacent plateau surface and also the stream bed below the section carries frequent boulders exceeding $1 \mathrm{~m}$ in diameter. We suspect that the original thickness of the diamict was substantially larger, but that it is now reduced as a result of solifluction and erosion towards the river valley.

The occurrence of a till in a high position over plateaux/interfluves between the river valleys is also very evident from the previously mentioned slump areas that are driven by back-wasting into the permafrost. The backwasting takes place just below the contact, and continues upwards in the covering unit-F sorted sediments, which thaw out and drain much more readily. The unit-E diamict is thus nearly impossible to dig out in the precise in situ position. However, we believe that this was nevertheless possible at site ARl, where a 0.5 -m-thick diamict was dug out in the permafrost, leaving a $0.5-\mathrm{m}$ gap up to the overlying unit-F sediments (Fig. 8).

Unit E: interpretation. Because of the poor exposure of the unit-E diamict, only little of its internal characteristics are revealed, and no fabric analysis could be carried out. We can therefore only conclude that it represents a glacial till of considerable areal coverage, as it forms the topmost deposit over all high ground when not covered by the unit-F marine deposits. The thickness seems to be less along low-angle interfluvial slopes towards the present river valleys, presumably as a result of solifluction processes, and eventually just forms a cobble-boulder residual on top of unit-D marine sediments, as is the case at the AR3 and AR4 sections.

Unit F: description. Unit $\mathrm{F}$ is exposed in section AR 1 (Figs. 5, 8b), where it forms a 2.4-m-thick slightly upward-coarsening succession. The deposit is quite uniform, with massive, sometimes gravelly, coarse to medium sand, interbedded with massive to planar parallel-laminated fine sand and silt, and with the silt beds being less frequent higher in the succession, at the same time as massive sand beds become thicker and coarser. Paired, in situ bivalves are abundant in the lower part, whereas half-shells and shell fragments become dominant in the upper part of the sediment sequence. $H$. arctica is the dominant species, followed by M. truncata and $A$. borealis. Less frequent occurrences include S. groenlandicus, $M$. calcarea and fragments of $C$. islandicus, the gastropods Trichotropis borealis and Neptunea ventricosa, and the barnacle Balanus balanus. The uppermost ca. $1 \mathrm{~m}$ of the unit-F sediments was inaccessible for logging, but indicated even coarser sediment towards the surface.

A mollusc sample yielded an infinite ${ }^{14} \mathrm{C}$ age ( $>40$ Kya; Table 3), and two ESR ages cluster at 83 and $86 \mathrm{Ky}$ (Table 4).

Unit F: interpretation. The interlaminated silts and sands with an abundant mollusc fauna, followed by massive sand and gravelly sand, suggest a transition from 

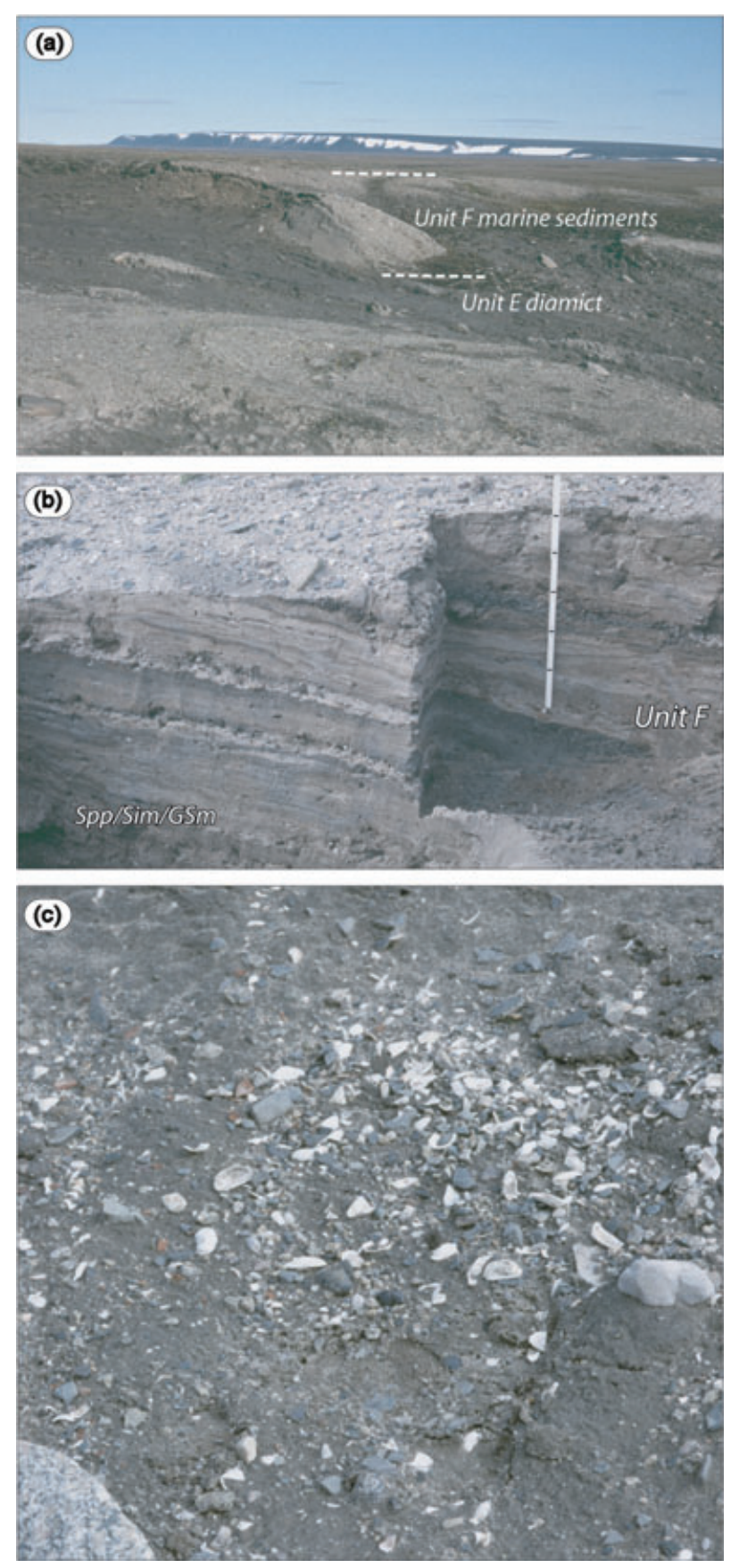

Fig. 8 (a) Slump area at site Anjeliko River 1 with unit-E diamict below unit-F marine sediments. (b) Interbedded unit-F gravelly sand, sand and silt. (c) Marine molluscs on the slump surface in (a), emanating from the back-wasting unit-F marine sediments.

shoreface to foreshore, and eventually to a beachface environment. We believe the environmental change to be caused by glaciostatic uplift of the area. The altitude of the beachface sediments at site ARl is at the minimum level

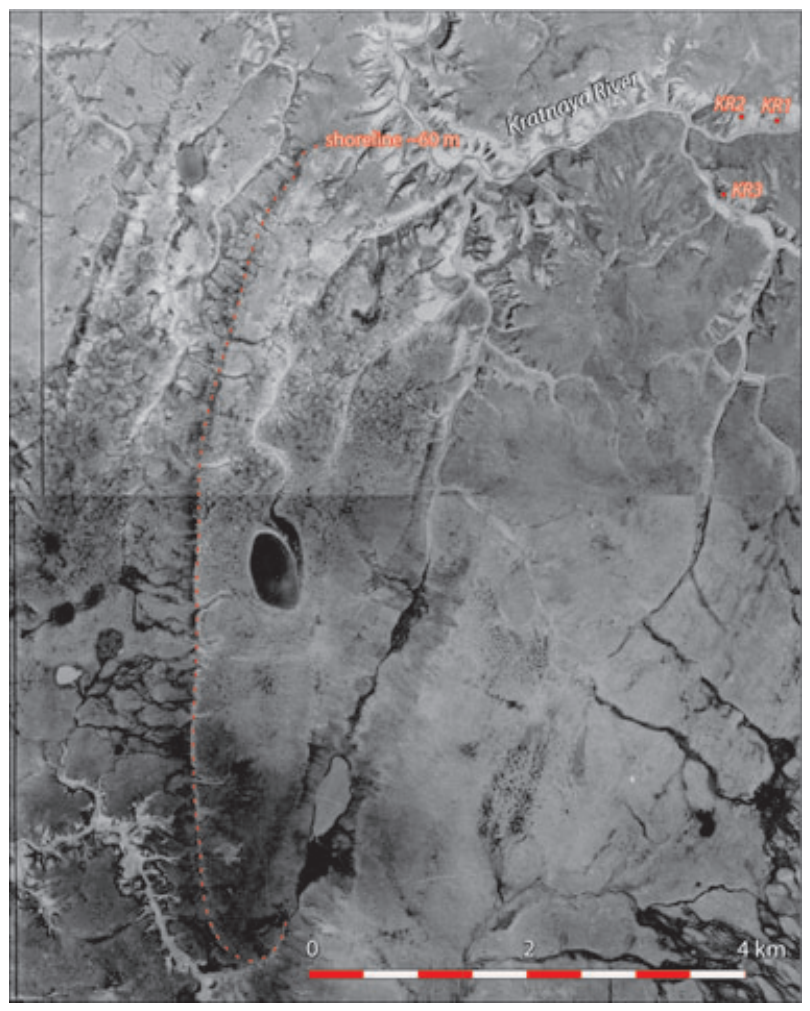

Fig. 9 Aerial photograph of the upper Kratnaya River valley, showing the position of the sedimentologically investigated sites (KR1-3). Note the prominent shore terrace at aproximately $60 \mathrm{~m}$ a.s.l., facing west.

of this marine phase: unit-F marine sediments can be followed to an altitude of at least $80 \mathrm{~m}$ a.s.l. in the Anjeliko River area.

\section{Kratnaya River area}

The stratigraphic framework along the Kratnaya River (Fig. 2a) is more or less the same as along the Anjeliko River: Cretaceous sediments dominate from the valley floor to the valley top, up to about $5 \mathrm{~km}$ inland from the coast. Further up-river, post-Cretaceous sediments, lying as palaeobasin/valley fills, were documented from three

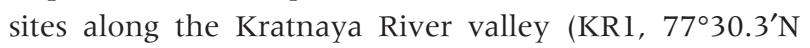
$103^{\circ} 12.3^{\prime} \mathrm{E}$; KR2, $77^{\circ} 30.3^{\prime} \mathrm{N} 103^{\circ} 11.8^{\prime} \mathrm{E}$; KR3, $77^{\circ} 30.0^{\prime} \mathrm{N}$ $103^{\circ} 11.8^{\prime} \mathrm{E}$; Fig. 9). The most complete section is KRl, starting about $5 \mathrm{~m}$ above the present river bed at $31.5 \mathrm{~m}$ a.s.l., and ending at $43.0 \mathrm{~m}$ a.s.l., and thus exposing $11.5 \mathrm{~m}$ of sediment. The Quaternary sediments continue upwards along an erosional low-angle slope to about $52 \mathrm{~m}$ a.s.l., but were inaccessible for excavation/logging. The exposed sediments are divided into four units, units A-D (Fig. 10), all of which can be correlated to the Anjeliko River area, but possibly with some uncertainty 


\section{Serebryanka River 2}
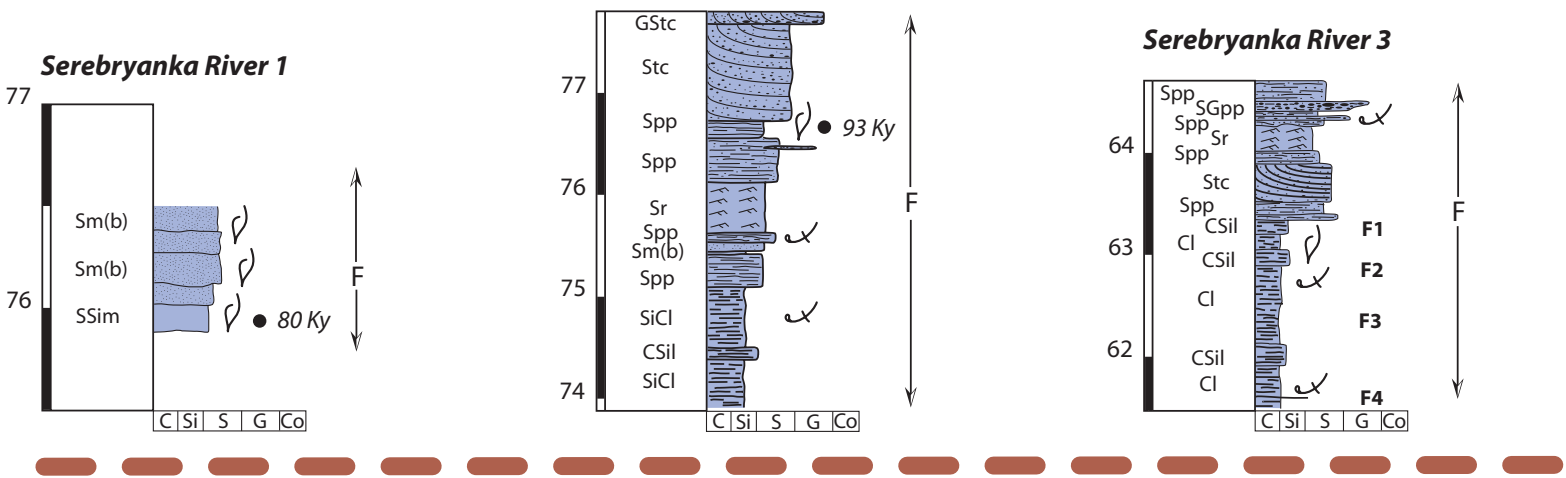

Kratnaya River 3

\section{Kratnaya River 1}
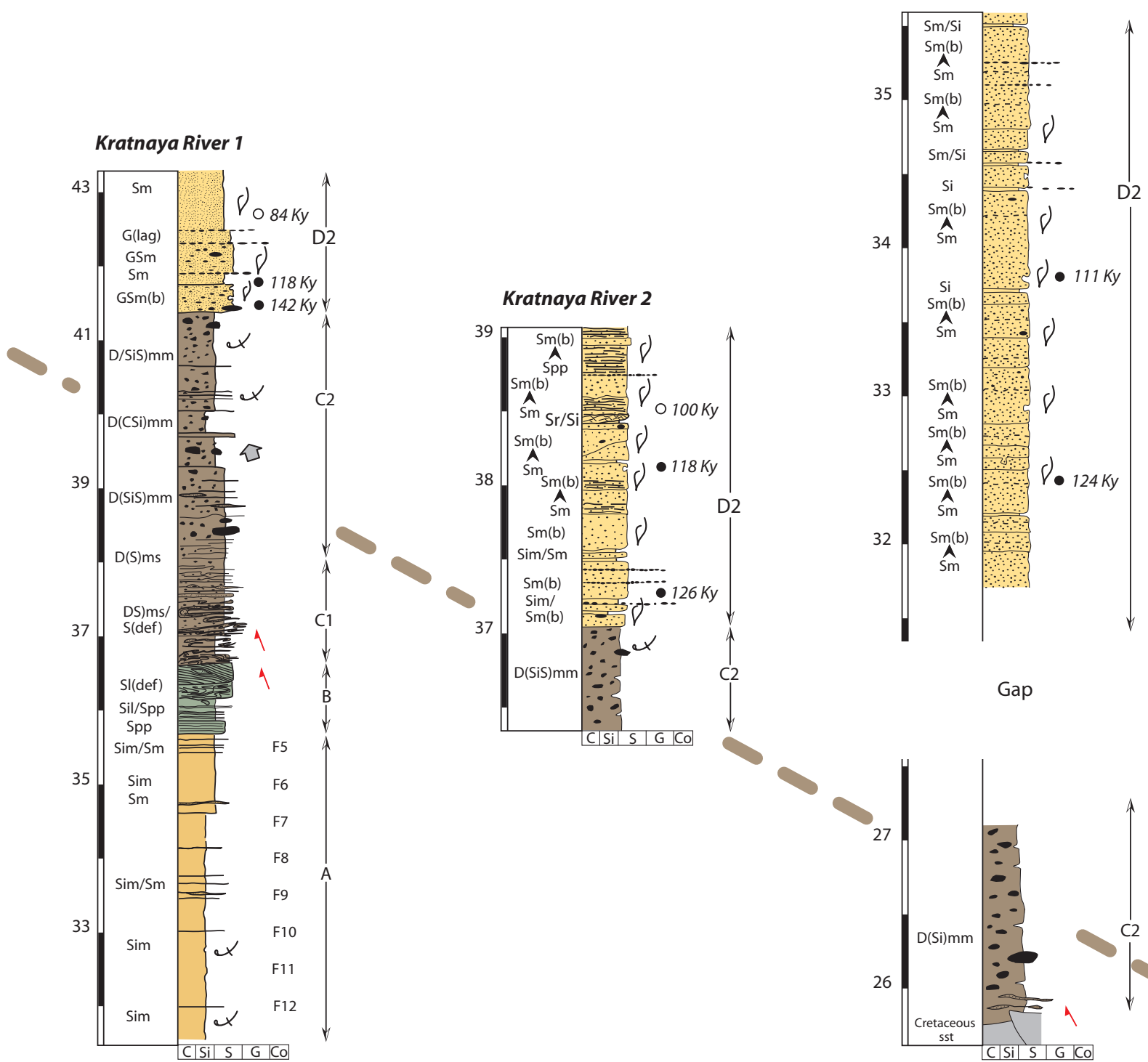

37

Kratnaya River 2
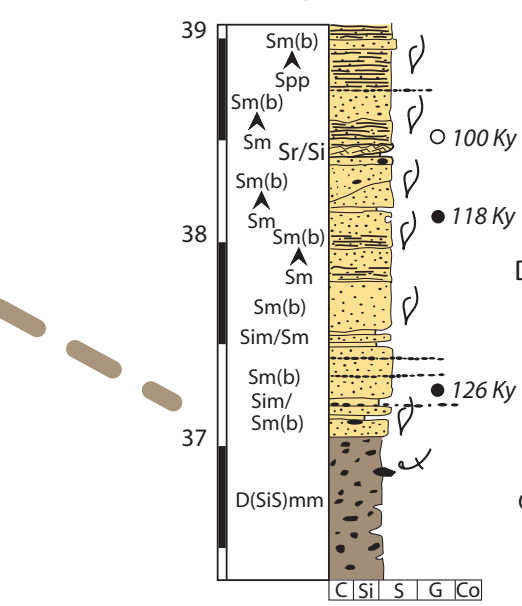

Gap
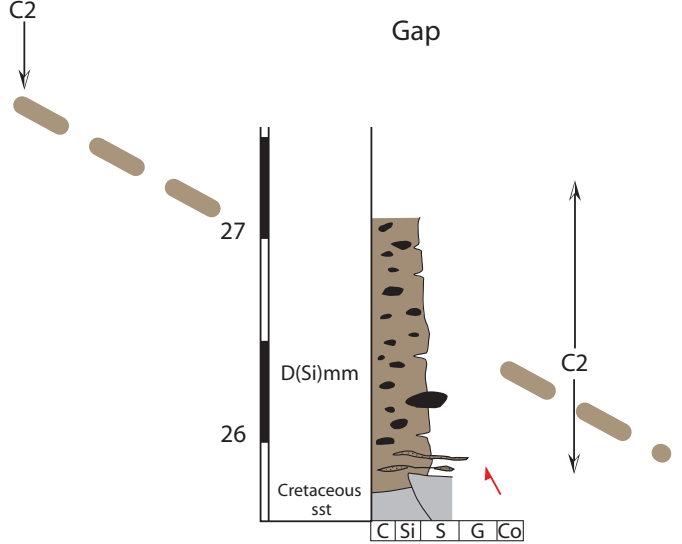

Fig. 10 Stratigraphic logs for sites in the Kratnaya River area (see Fig. 9 for location). Note that the SER1, KR2 and KR3 logs are drawn in double-height scale. Legend as for Fig. 5. Colour codes for the units are the same as in Fig. 4. 
for unit B (see below). Units E and F could not be identified in accessible exposures, but are believed to be present in the uppermost part of the Quaternary succession (see below).

Raised marine sediments, covering a plateau south of the Kratnaya River are, as is the case at Anjeliko River, delimited in the west by a pronounced escarpment. This 2-3-m-high escarpment, with its base at ca. $60 \mathrm{~m}$ a.s.l., can be followed at a constant altitude for about another $6 \mathrm{~km}$ (Fig. 9). Also, it is interpreted here as a marine regressive shoreline.

Unit A: description. Unit A is only exposed at site KR l (Fig. 10), where it has a minimum thickness of $4.2 \mathrm{~m}$. Here it forms a massive to vaguely stratified silt, interbedded at a varying frequency by sand beds, ranging from just a few millimetres up to $5 \mathrm{~cm}$ in thickness. A few molluscs were encountered, but it was not possible to extract them in identifiable pieces. The sediments were sampled at $0.5-\mathrm{m}$ intervals for examination of the foraminiferal fauna (eight samples), but all were found to be barren.

Unit A: interpretation. The silt is interpreted as being deposited out of suspension in a full offshore marine environment. The relatively frequently occurring sand intrabeds, some of them with a considerable thickness, are suggested to be distal deposits from high-density turbidity currents, possibly generated during storm events (e.g., Elliot 1986). As neither datings nor faunal information are available, the stratigraphical/chronological position of unit A is uncertain. However, a not too bold suggestion is that it correlates to unit A in the Angelico River area, and should thus be of Pliocene age.

Unit B: description. A 1.3-m-thick sequence of planar parallel-laminated sand interbedded with massive silt can possibly be correlated with unit-B sediments at Anjeliko River. The upper 0.9-m section is heavily tectonized, and shows folds and thrusts (Fig. 1la, f). Sand intraclasts in the silt show both lenticular as well as pinch-and-swell geometries, and more stretched-out sand intrabeds reveal intricate folding. The degree of deformation increases towards the contact with the above-lying diamict.

Unit B: interpretation. Only a small part of unit B is exposed, and most of the sediments are highly deformed as a result of glacial tectonics, which transform them into a glacitectonite. Only a little can therefore be concluded on the original depositional environment, especially as the undeformed parts of the sediment succession do not copy the facies association revealed in unit-B sediments in the Anjeliko River area. However, because the sedi- ments occur in the same stratigraphic position, and because there is no indication of a marine origin, it is suggested that they correlate with the terrestrial fluvial unit-B sediments in the Anjeliko area.

Unit C: description. Unit $\mathrm{C}$ is a diamict, occurring at all Kratnaya River sites. At site KR3 the diamict is situated on top of Cretaceous sandstone, the latter being thrust along reverse fault planes (Fig. 11c; thrust fault plunging toward the SSE). At site KR1, underlying unit-B sand and silt is heavily tectonized (see above) below the basal contact with the diamict. The diamict above the contact can be divided into two subunits. The lower subunit $(\mathrm{Cl}$; ca. $1 \mathrm{~m}$ thick) is a sandy/silty and clast-rich diamict, intensely intrabedded with thin sand beds showing pinch-and-swell geometries, giving the diamict a stratified appearance (Fig. lla). Some thicker sand beds are folded repeatedly in isoclinal, overturned folds (Fig. 11b), and some sand occurs as detached clasts with internal folding. The measured fold axes strike at about northeast-south-west (Fig. 7).

Subunit C2 is a matrix-supported, massive, sandy/silty diamict. It is rich in small clasts with diameters of $10-15 \mathrm{~cm}$, although boulders do occur. The largest boulder observed in the section is about $0.7 \mathrm{~m}$ in diameter. Sand occurs as thin, sometimes folded intrabeds, but also as lens-shaped sand inclusions. The uppermost metre is rich in shell fragments. One fabric analysis was carried out in the $\mathrm{C} 2$ diamict at site $\mathrm{KR} 1$, revealing a statistically strong preferred clast long axis orientation $\left(S_{1}\right.$ eigenvalue, 0.754 ; Fig. 7$)$. The $V_{1}$-axis orientation (azimuths towards $171^{\circ} / 6^{\circ}$ ) suggests a stress-transfer direction from the SSE.

Unit C: interpretation. The intense folding in both unit-B and $-C$ sediments makes the placing of the boundary between the two somewhat arbitrary, as there is a gradational change from the slightly deformed, sorted sediments of unit B to the diamict of unit C, with the latter having very little sediment input from unit B. The dominance of deformed unit-B sediments in the lower part of unit Cl justifies classification as a type-A glaciotectonite (Evans et al. 2006), grading into a type-B deformation till. The gradual upwards decrease of subhorizontal sand lamina, interpreted to be a shear lamination, indicates the gradual cut-off from the underlying sorted sediment source, and also suggests increasing strain rates, eventually with total homogenization of the deforming bed. The deforming bed was probably thin, with gradual vertical accretion as a result of frictional freezing of the sediment. This is indirectly indicated from fabric data: unimodal and clustered fabric shapes are suggested to be indicative of thin deforming 

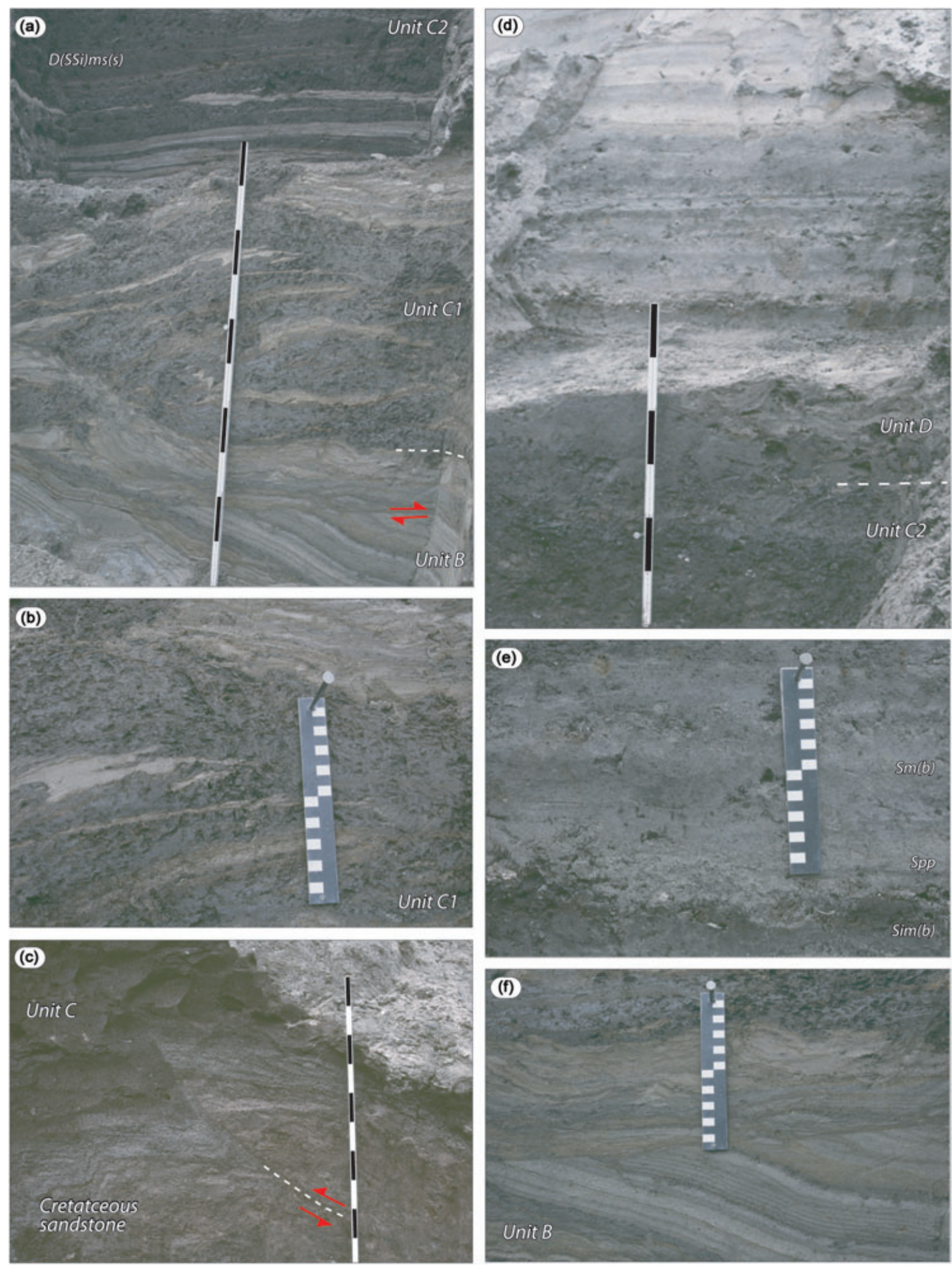
Fig. 11 (a) The contact between unit-B sorted sediments and unit-C diamict at site KR1. Unit-B sediments are folded and thrusted, and are upwards incorporated into the lower part of the unit-C1 diamict, here being isoclinally folded, and higher up forming subhorizontal shear lamination in the stratified diamict. (b) Detail of folds in (a). (c) Unit-C diamict on top of Cretaceous sandstone, site KR3. Note the pronounced listric reverse fault thrust, plunging towards the SSE. (d) Unit-C diamict, overlain by interbedded unit-D marine sand and silt. (e) Detail of (a), showing primarily interbedded silt and planar parallel-laminated sand, with both types of beds bioturbated in distinct horizons, and obscuring the primary structures. ( $f$ ) Detail in (a) of thrust in unit-B sediments below the contact with the unit-c diamict. $10 \mathrm{~cm}$ intervals on scale bar.

bed zones (Hart 1994; Benn 1995; Hart \& Rose 2001) undergoing ductile shear (Benn \& Evans 1996). All structural data taken together imply that the ice movement causing the deformation of the Cretaceous bedrock, and of unit-B sand, as well as the deposition of unit-C diamict, was from a SSE sector, i.e., directed towards the Kara Sea shelf.

Unit D: description. Unit D is exposed in all sections (Fig. 10) with very similar facies composition. The thickest succession was encountered at site KR3, here being $3.9 \mathrm{~m}$ thick. It is dominated by 10-30-cm-thick sand beds, having a more or less clearly visible primary planar parallel lamination, interbedded with 1-2-cm-thick massive silt beds, and thin gravel/pebble stringers (Fig. 11d). Minor facies constituents are sets of ripple-laminated sand and the occasional scour-trough infillings, in which the latter are associated with an increased frequency of half-shells and shell fragments. The KR2 sediment succession also shows a slight coarsening upward trend and a change in the frequency of silt interbeds. A lowfrequency occurrence of out-sized floating clasts (MPS, $10 \mathrm{~cm}$ ) within the sand beds was observed.

All beds are abundant in paired molluscs. The gravel lags are also very rich in single valves and shell fragments, as are the occasionally occurring scour-trough bottoms. The sand beds are very characteristic in their appearance (Fig. 1 1e). They often start with yellow, massive or planar parallel-laminated sand, which continues with a diffuse boundary into grey-yellowish, slightly more fine-grained sand, with clear evidence of bioturbation, including dragging down of silt during the burrowing process. H. arctica, $M$. truncata and $A$. borealis are the dominating species, but also a few specimens of $M$. calcarea and $S$. groenlandicus occur. Shell surfaces show borings from P. ciliata (frequent) and Natica (a few).

One mollusc sample from unit D yielded an infinite ${ }^{14} \mathrm{C}$ age (>40 Ky; Table 3 ). Six ESR ages form a cluster at 111 , $118,118,124,127$ and $142 \mathrm{Ky}$ (Table 4), whereas two OSL datings gave ages of 84 and $100 \mathrm{Ky}$ (Table 5).

Unit D: interpretation. The sedimentary information from unit D is fragmentary, as only the lower part of the total sediment succession was accessible. Without any deeper-marine deposits on top of the unit-C till, the suc- cession starts as quite shallow-marine deposits, indicating a transition from an offshore to a shoreface depositional environment. The gravel stringers probably represent storm-induced pebble out-runners. The sediments seem, however, to generally have been deposited below the wave base, as indicated from the abundant fossil molluscs. The molluscs have to a large extent bioturbated most deposits to a considerable depth, dragging down both silt and pebbles, and making the upper part of the sand beds close to diamict in character. The coarsening upward trend at site KR2 suggests isostacy-driven basin emergence; however, this could not be documented because of the lack of observable beach-face sediments, as was the case for unit D in the Anjeliko River area.

Units E and F. As previously stated, approximately $9 \mathrm{~m}$ of sediment is inaccessible for excavation above the logged unit D at site KR1, ending with a plateau surface at about $52 \mathrm{~m}$ a.s.l. towards the north. South of the Kratnaya River the landscape is more dissected as a result of erosion, and just the plateau surface at $52 \mathrm{~m}$ a.s.l. remains as a few flat-topped sediment mounds. Shallow trenches reveal sand interbedded with thin silt beds below a coarser gravelly top, and the sediments contain marine molluscs (Hiatella and Mya). However, because of the permafrost, no section could be dug deep enough to expose original bedding and in situ molluscs. Large boulders of sizes not found within unit-D sediments at the KRl-3 sections are scattered on the ground surface between the sand mounds. We believe that these sediments possibly represent the sedimentary units E and F, as described from the Anjeliko River area. The scattered boulders should therefore represent remnants of the unit-E till, lying stratigraphically above the unit-D marine sediments, and the gravel, sand and silt in the erosional mounds should represent the topmost marine unit F.

\section{Serebryanka River area}

The Serebryanka River is a major river draining the area east of the Astrup Mountain (Fig. 2a). The area was subjected to a shorter reconnaissance tour, revealing marine sediments up to at least $78 \mathrm{~m}$ a.s.l. The sediments were poorly exposed, and stratigraphic relations to diamict 
sediments were not shown in occurring shallow sections. However, three sections with marine sediments were logged (Fig. 2a; SERl-2, $77^{\circ} 26^{\prime} \mathrm{N} \quad 103^{\circ} 38^{\prime} \mathrm{E} ;$ SER3, $\left.77^{\circ} 35^{\prime} \mathrm{N} 103^{\circ} 37.8^{\prime} \mathrm{E}\right)$.

Sediment description. The SER2 section reveals a 9.1$\mathrm{m}$-thick coarsening upward succession, starting with laminated silty clay. The succession continues with planar parallel-laminated sand, interbedded with a few thin beds of massive silt, and the occasional bed of gravelly sand, with a basal scour contact, ending in a 1.8 -m-thick bedset of trough cross-laminated sand and gravelly sand. The same facies pattern could be observed in the SER3 section (8.2 $\mathrm{m}$ thick). The middle parts of the sections have an abundant occurrence of in situ molluscs: $H$. arctica, $M$. truncata and $A$. borealis. The foraminiferal fauna, as shown from four samples in the lower part of the SER3 section, are poor in number, but are relatively diverse in species (Table 2). They are dominated by E. excavatum. Assessory species include Cassidulina reniforme, Islandiella norcrossi, Haynesina orbiculare, C. lobatulus and Islandiella helenae, indicating an Arctic shelf assemblage. Single specimens of the pre-Pleistocene species C. grossus and Cibicides scaldisiensis are considered to be reworked.

Two mollusc samples yielded ESR ages of 93 and $78 \mathrm{Ky}$ (Table 4).

Interpretation. The SER2-3 massive to laminated clays and silts with floating out-sized clasts suggest gradually shallowing offshore marine conditions, with interbedded sands representing storm events. Upward change into planar parallel-laminated sand, often with a rich mollusc fauna, followed by cross-laminated sand and gravelly sand, and the occasional pebble and cobble lags, suggest transition from the offshore to a shoreface environment, and eventually to a foreshore/beachface environment, indicating a full isostacy-driven regressional sediment sequence.

\section{Between-site correlations, event stratigraphy, chronology and regional outreach}

Based on similarities in stratigraphic positions, facies composition and patterns of vertical facies change in defined sedimentary units, and/or on consistencies or groupings of retrieved sediment ages of described fluvial and marine units, we consider that we have documented three distinct marine events. As the marine sediments are intercalated with glacial tills, we further suggest that two of these marine events, together with their underlying tills, represent two full glacial cycles of isostatic compensation, coupled with marine inundations with deglaciation.
The first marine event, manifested by unit A in the Anjeliko and Kratnaya river valleys (Fig. 4b), could not be demonstrated to be connected with any regional till. However, the frequent occurrence of drop stones in the lower part of the succession suggests ice rafting, and possibly a glaciomarine origin. The only retrieved dating suggests Middle to Early Pleistocene age, whereas the foraminiferal composition clearly shows a Pliocene age (>1.8 My). The presence of drop stones indicates deposition during a period after the main onset of northern hemisphere glaciations.

The foraminiferal assemblage of unit A is very similar to assemblages found across Arctic Canada and Greenland (e.g., Feyling-Hanssen 1976, 1980; Feyling-Hanssen et al. 1983; McNeil 1990; Fyles et al. 1998), and may be correlated with the $C$. grossus zone and zone $\mathrm{H}$ from Baffin Island (Clyde Foreland and Quivituq Peninsula, respectively; Feyling-Hanssen 1976, 1980) and with zone I from Lodin Elv, East Greenland (Feyling-Hanssen et al. 1983). This indicates the existence of a similar circum-Arctic fauna at that time. The species composition indicates a sub-Arctic climate and an inner shelf environment with salinities of $>30 \%$ o (e.g., Seidenkrantz \& Knudsen 1994; Steinsund et al. 1994).

The unit-B fluvial sediments (Fig. 4b) are also quite unconstrained when it comes to their chronostratigraphic position. The unit-B sediments in the Anjeliko River area form a substantial part of the total sediment cover. They suggest a period of fluvial erosion and deposition, as indicated from the frequent inclusion of organic remains, preferentially coal and mollusc fragments, from the underlying Cretaceous sandstone. The timing of this event is problematic: the two retrieved OSL ages indicate an Eemian age (MIS 5e), which must be considered erroneous as unit B is stratigraphically constrained by the overlying unit- $\mathrm{C}$ diamict, which is in turn overlain by marine unit D, with a clear Eemian age, as indicated from mollusc datings from several sites. We can only conclude that these fluvial sediments are pre-late-Saalian (pre-MIS 6) in age.

The first glacial/deglacial cycle encompasses the unit- $\mathrm{C}$ basal till and unit-D marine sediments (Fig. 4b), which are all present in the Kratnaya River sections 1-3 and Anjeliko River sections 3 and 4 . The deposition of the till is associated with deep-reaching deformation into the underlying unit-B sediments/Cretaceous sandstone, and with wet-based thermal conditions with a deforming bed zone. All structural data imply an ice-movement direction from the SSE, i.e., towards the Kara Sea shelf. The age envelope from nine ESR datings on molluscs in the above-lying marine sediments is 156-111 Ky, with a mean age of $131 \mathrm{Ky}$, suggesting a Late Saalian to Eemian (MIS 6/5e) transition (Lambeck \& Chappell 2001) for the 
marine sequence, and therefore a Saalian age for the unit-C till (MIS 6). Four OSL ages, spanning from 135 to $79 \mathrm{Ky}$ (mean, $100 \mathrm{Ky}$ ), are considered to be less reliable as age indicators for unit D. It was not possible to identify an absolute highest marine limit associated with unit D: the highest position logged was ca. $59 \mathrm{~m}$ a.s.l. (AR3 and $4)$, but surface mapping has shown it to reach at least $80 \mathrm{~m}$ a.s.l. However, if the observations by, for example, Mirošnikov (1959) and Šnejder (1989), from other locations on the Chelyuskin Peninsula, are correct (i.e., that these marine strata correlate with our unit-D MIS 5e sediments) with a highest altitude of up to $140 \mathrm{~m}$ a.s.l., then the distribution of the Eemian/MIS 5e sediments on Cape Chelyuskin is in line with the highest observed Eemian shorelines in Severnaya Zemlya, occurring there up to 125-140 m a.s.l. (Möller et al. 2006).

The second glacial/deglacial cycle encompasses unit-E basal till, followed by a regressional sequence initiated with shoreface to foreshore marine sediments, and capped by beachface sand and gravels (unit F; Fig. 4a). The unit-F sediments, lying in a clear stratigraphic context at site ARl, i.e., above unit-E till, are correlated with the sediment successions along the Serebryanka River (sites SER 1-3). All have similar facies succession and ESR age envelopes. The mean ESR age for four datings is $86 \mathrm{Ky}$, with a close cluster of ages (age envelope 80-93 Ky), indicating an Early Weichselian stadial/ interstadial transition, most probably at MIS $5 \mathrm{~d} / 5 \mathrm{c}$ (Lambeck and Chappell 2001). The underlying till (unit E) thus represents the Early Weichselian glaciation that reached its maximum south of the Byrranga Mountains, at about 90 Kya (Möller et al. 1999; Hjort et al. 2004; Svendsen et al. 2004). Unfortunately, no structural data indicating ice dispersal directions could be retrieved from this till, and it can only be concluded that it represents a phase of wet-based thermal conditions. It was not possible to identify an absolute highest marine limit associated with unit F. However, the highest logged position is ca. $80 \mathrm{~m}$ a.s.l. in the Serebryanka River sections, indicating a substantial glacial loading of the crust during the preceding glacial event.

In Fig. 12, the Chelyuskin glacial stratigraphy is set into a regional context. The Chelyuskin unit-D marine sediments are thus correlated with the Kazantzevo/Eemian marine deposits, described from a large number of sites on the Taymyr Peninsula (Fig. 12a) (Urvantsev 1931; Saks 1953; Kind \& Leonov 1982), and from a number of sites from the Severnaya Zemlya archipelago (Bolšijanov \& Makejev 1995; Möller et al. 2006). The reported Eemian sediments range from deep-marine to beachface sediments. The latter reach altitudes of up to $130 \mathrm{~m}$ a.s.l. south of the Byrranga Mountains, inside the southern margin of the KSIS, and as high as 125-140 m a.s.l. in
Severnaya Zemlya, only $200 \mathrm{~km}$ inside the shelf brake and the northern margin of the Saalian KSIS (Möller et al. 2006).

Weichselian ice-sheet extent reconstructions carried out under the Quaternary Environment of the Eurasian North (QUEEN) research umbrella (Astakhov 1998; Svendsen et al. 1999; Hjort et al. 2004; Svendsen et al. 2004) suggest that the Weichselian maximum of a KSIS in the south is demarcated by the Jangoda-SyntabulBaikuronyora ridges, i.e., the JSB line (Fig. 12b), which is a wide push moraine that can be followed for some $850 \mathrm{~km}$ (and occurred ca. 90-100 Kya; MIS 5d). The subsequent ice recession is associated with marine inundation south of the Byrranga Mountains, and with deposition of marine sediments and deltas reaching $100 \mathrm{~m}$ a.s.l. along the southern Byrranga Mountains, known as the "Ledyanaya gravel event", and dated to 95-70 Kya (26 ESR ages and five OSL ages; Möller et al. 1999; Hjort et al. 2004). The KSIS recession temporarily halted north of the Byrranga Mountains, and constructed parts of the complex North Taymyr ice-marginal zone (NTZ; Fig. 12b) (Alexanderson et al. 2001; Alexanderson et al. 2002). On the northern flank, the KSIS also seems to have expanded to the continental shelf margin in the Early Weichselian, as indicated by IRD peaks in sediment cores retrieved from the shelf, interpreted to represent advance/retreat phases of the KSIS (Knies et al. 2001). The unit-F marine sediments on Chelyuskin Peninsula thus fall within the frame of deglacial marine sediments (Fig. 12b) from the retreat phase of the Early Weichselian KSIS. The Kara Sea ice sheet readvanced southwards to the NTZ in the Middle Weichselian (OSL ages of ca. 70-54 Ky; Alexanderson et al. 2001; Alexanderson et al. 2002) (Fig. 12c). However, the sites from the Chelyuskin Peninsula presented here seem to have been located outside of this Middle Weichselian ice advance (Fig. 12c). This was also the case during the last Late Weichselian ice advance to the NTZ (Fig. 12d).

From an inception paradigm in which the ice sheets in north-west Siberia started to grow over mountain areas (e.g., the Byrranga Mountains, Ural Mountains, etc.), and then flowed out into lowland areas (e.g., Urvantsev 1931; Saks 1953), there has been a shift into a paradigm suggesting the repeated build-up of thick ice sheets on the shallow shelves of the Barents and Kara seas (e.g., Grosswald 1980, 1998; Kind \& Leonov 1982; Astakhov 1998). The substantial loading from such continental-scale ice could explain the occurrence of high raised beaches, including the 130140-m a.s.l. Saalian/Eemian-inundation shorelines on October Revolution Island, which are among the highest described from the Eurasian Arctic. Using such shoreline evidence and dated ice-marginal formations, the maximum KSIS thickness during, e.g., the Saalian, is 

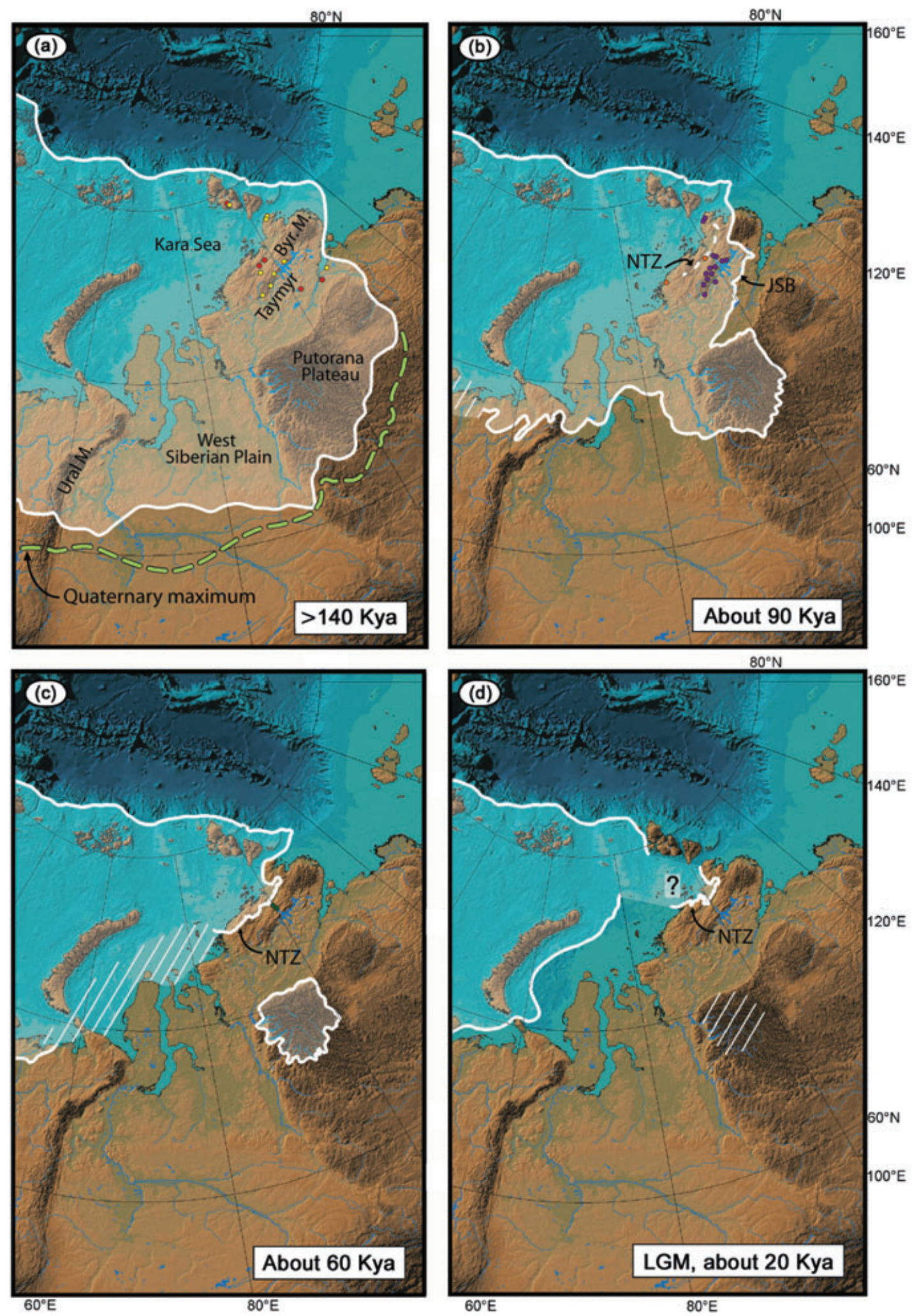
Fig. 12 Quaternary Environment of the Eurasian North (QUEEN) reconstructions of ice-sheet extent over the eastern Eurasian Arctic, adapted from Svendsen et al. (2004). (a) The Late Saalian and the Quaternary maximum ice-sheet extent. Red dots are electron spin resonance (ESR)-dated sites on the Taymyr Peninsula, with presumably Tobol interglacial marine sediments (MIS 9?) (Bolshiyanov \& Molodkov 1998). Yellow dots within and south of the Byrranga Mountains are ESR-dated sites with Kazantzevo/Eemian marine sediments, according to Bolshiyanov \& Molodkov (1998), whereas those in the north are ESR and optically stimulated luminescence (OSL)-dated Eemian marine sediments on the Chelyuskin Peninsula (this study) and in Severnaya Zemlya (Möller et al. 2006). (b) The Early Weichselian (EW) maximum ice-sheet extent. Violet dots are ESR-and OSL-dated sites with marine/marine deltaic sediments deposited during ice recession towards the Byrranga Mountains; orange dots are sites with OSL-dated glaciolacustrine deltaic sediments from an ice-dammed lake in front of the North Taymyr ice-marginal zone (NTZ; Hjort et al. 2004; Hjort \& Funder 2008). Abbreviations: JSB, the JangodaSyntabul-Baikuronyora line, the EW maximum on Taymyr; NTZ, the NTZ at EW deglaciation. (c) The Middle Weichselian maximum ice-sheet extent. Green dots are OSL-dated sites, some containing glaciolacustrine sediments in an ice-dammed lake in front of the NTZ, and other dots sites with sediments in the out-flow areas of that ice-dammed lake, according to Hjort et al. (2004). Note that the Chelyuskin Peninsula is outside the margin of this ice advance. (d) The Late Weichselian maximum ice-sheet extent, just reaching inside the west coast of the Taymyr Peninsula to the NTZ, but neither covering the Chelyuskin Peninsula, nor the Severnaya Zemlya archipelago (Möller et al. 2006).

estimated to be 3000-3300 m by earth rheological inverse modelling (Lambeck et al. 2006). More recent reconstructions of Eurasian Ice Sheet build-ups and decays have confirmed this latter paradigm (e.g., Möller et al. 1999; Alexanderson et al. 2001; Alexanderson et al. 2002; Hjort et al. 2004; Svendsen et al. 2004; Astakhov \& Mangerud 2005; Larsen et al. 2006).

However, there is now growing evidence that the latter paradigm could be combined with the first. Structural and textural evidence from tills and sub-till sediments at a number of stratigraphic positions in Severnaya Zemlya imply subglacial deformation and deposition during expansions of local ice caps (Möller et al. 2006). This is evidenced by the raised beaches indicating the expansion of a thick Kara Sea-based ice sheet, as the high marine limits cannot be explained by local glaciations alone. The same pattern is now also documented on the Chelyuskin Peninsula. The unit- $C$ till, suggested to be Saalian in age, indicates an ice flow towards the Kara Sea shelf, and not in the opposite direction as would be expected from a Kara Sea shelf-based ice sheet. Such expansions of local ice caps are also suggested by, e.g., Forman et al. (1999, 2002), Lokrantz et al. (2003) and Hjort \& Funder (2008). These local ice caps were characterized by wet-based thermal regimes. As suggested by Möller et al. (2006), these local ice domes in highland areas and along the perimeter of the Kara Sea grew and coalesced on the adjacent shelf with globally falling sea levels. As a larger ice dome formed, this initiated the redistribution of ice drainage and basal thermal regimes. A fully developed KSIS drained preferentially towards the Arctic Ocean to the north, as ice streams developed along, e.g., the St. Anna and the Voronin troughs, but also expanded southwards across the Byrranga Mountains. Stratigraphic data from Severnaya Zemlya suggests cold-based thermal regimes over "inception islands" during maximum ice sheet extent, because there is a lack of tills associated with Kara Sea sources, as also seems to be the case on the Chelyuskin Peninsula.

\section{Conclusions}

On the basis of our field data from the Chelyuskin Peninsula, and from comparisons with adjacent areas, we draw the following conclusions.

- At least two distinct sedimentologic and geochronologic glacial/deglacial events are identified. Till sheets (till units $\mathrm{C}$ and $\mathrm{E}$ ) interbedded with marine sediments (units D and F), exposed in stratigraphical sections, and raised beach sequences at altitudes of up to $80 \mathrm{~m}$ a.s.l., relate to repeated glacial loading by Kara Sea-based ice sheets.

- Our dating programme (AMS ${ }^{14} \mathrm{C}, \mathrm{ESR}$ and OSL) shows major glaciations, followed by deglaciation and marine inundation, during MIS 6-5e, and most probably during MIS 5d-5c.

- There are no observed tills and raised marine evidence from the Middle Weichselian (MIS 4-3) or from any Late Weichselian ice advance (MIS 2) on the Chelyuskin Peninsula.

- Structural and textural evidence from tills and sub-till sediments on the Chelyuskin Peninsula suggest that ice at least once, but most probably twice, advanced from the south, implying expanding, wet-based local ice moving towards the Kara Sea.

- The build-up of local ice on the Chelyuskin Peninsula, as well as in the Severnaya Zemlya archipelago, and probably in several other areas along the perimeter of the Kara Sea, reflects the initiation stage of a Kara Sea ice sheet. Local ice caps during the inception phases were wetbased, as indicated by till deposition and subglacial deformation. In contrast, the lack of tills associated with Kara Sea ice sheets reflects cold-based ice sheet coverage at a later stage in the glacial cycle. The presence of highly localized raised marine sediments and beaches reflect regional isostatic deformation, with ice sheet loading of $>2000$ m (Lambeck et al. 2006) over the Kara Sea shelf, and large-scale glaciation of the Eurasian north. 


\section{Acknowledgements}

This work has been carried out as a cooperative venture between Lund University, Sweden, and the Arctic and Antarctic Research Institute, St. Petersburg, Russia, within the EU-financed Eurasian Ice Sheets programme (contract no. ENV4-CT97-0563), and under the European Science Foundation's Quaternary Environments of the Eurasian North umbrella. Specific project funding was provided through a grant from the Swedish Research Council to P. Möller (contract no. G-650-19981571/2000), and from the Danish Natural Science Research Council to M.-S. Seidenkrantz (no. 9502425). The logistics for the 1998 and 1999 expeditions were planned and financed by the Swedish Polar Research Secretariat, and through subcontracts to INTAARI (St. Petersburg, Russia). Svend Funder, Geological Museum, Copenhagen University, Denmark, determined the mollusc species. Anatoly Molodkov, Tallin Technical University, Estonia, performed ESR dating, and provided background information on ESR dating. Andrew Murray at the Nordic Centre for Luminescence Research, Risø, Denmark, performed OSL dating, and provided background information and discussion on OSL dating problems. Svend Meldgaard Christiansen, University of Aarhus, carried out the laboratory treatment of the foraminiferal samples. To all these organizations and individuals, we proffer our sincere gratitude.

\section{References}

Alexanderson H., Adrielsson L., Hjort C., Möller P., Antonov O., Eriksson S. \& Pavlov M. 2002. The depositional history of the North Taymyr ice-marginal zone, Siberia-a landsystem approach. Journal of Quaternary Science 17, 361-382.

Alexanderson H., Hjort C., Bolshiyanov D.Y., Möller P., Antonov O., Fedorov G.B. \& Pavlov M. 2001. The North Taymyr ice-marginal zone-a preliminary overview and dating. Global and Planetary Change 31, 427-445.

Astakhov V.I. 1998. The last ice sheet of the Kara Sea: terrestrial constraints on its age. Quaternary International 45/46, 19-28.

Astakhov V.I. 2001. The stratigraphic framework for the Upper Pleistocene of the glaciated Russia: changing paradigms. Global and Planetary Change 31, 283-295.

Astakhov A. 2004. Middle Pleistocene glaciations of the Russian North. Quaternary Science Reviews 23, 1285-1311.

Astakhov V.I. \& Mangerud J. 2005. The age of the Karginsky interglacial strata on the lower Yenisei. Earth Sciences 403, 673-676.

Benn D.I. 1995. Fabric signature of subglacial till deformation, Breidamerkurjökull, Iceland. Sedimentology 42, 735-747.
Benn D.I. \& Evans D.J.A. 1996. The interpretation and classification of subglacially-deformed materials. Quaternary Science Reviews 15, 23-52.

Bolshiyanov D.Y. \& Molodkov A. 1998. Marine Pleistocene deposits of the Taymyr Peninsula and their age from ESR dating. In H. Kassens et al. (eds.): Land-ocean systems in the Siberian Arctic: dynamics and history. Pp. 469-475. Berlin: Springer.

Bolšijanov [Bolshiyanov] D.Ju. \& Makejev V.M. 1995. Arhipelag Severnaja Zemlja: oledenenie, istoria razvitija prirodnoj sredy. (Severnaya Zemlya archipelago: glaciation, nature history.) St. Petersburg: Gidrometeoizdat.

Cushman J.A. \& Grant U.S., IV 1927. Late Tertiary and Quaternary Elphidiums of the west coast of North America. San Diego Society of Natural History Transactions 5, 69-82.

Doppert J.W.C. 1980. Lithostratigraphy and biostratigraphy of marine Neogene deposits in the Netherlands. Mededelingen Rijks Geologische Dienst 32, 257-311.

Eidvin T. \& Nagy J. 1999. Foraminiferal biostratigraphy of Pliocene deposits at site 986, Svalbard Margin. In M.E. Raymo et al. (eds.): Proceedings of the Ocean Drilling Program, Scientific Results 162, 3-17.

Eidvin T., Riis F. \& Rundberg Y. 1999. Upper Cainozoic stratigraphy in the central North Sea (Ekofisk and Sleopner fields). Norsk Geologisk Tidsskrift 79, 97-128.

Elliot T. 1986. Siliclastic shorelines. In H.G. Reading (ed.): Sedimentary environments and facies. Pp. 155-188. Oxford: Blackwell Scientific.

Evans D.J.A., Phillips E.R., Hiemstra J.F. \& Auton C.A. 2006: Subglacial till: formation, sedimentary characteristics and classification. Earth-Science Reviews 78, 115-176.

Eyles N., Eyles C.H., Miall A.D. 1983. Lithofacies types and vertical profile models; an alternative approach to the description and environmental interpretation of glacial diamict and diamictite sequences. Sedimentology 30 , 393-410.

Feyling-Hanssen R.W. 1976. The stratigraphy of the Quaternary Clyde Foreland Formation, Baffin Island, illustrated by the distribution of benthic foraminifera. Boreas 5, 77-94.

Feyling-Hanssen R.W. 1980: Microbiostratigraphy of young Cenozoic marine deposits of Qivituq Peninsula, Baffin Island. Marine Micropaleontology 5, 153-184.

Feyling-Hanssen R.W. 1983. Quantitative methods in micropaleontology. In L.I. Costa (ed.): Palynologymicropalaeontology: laboratories, equipment and methods. Norwegian Petroleum Directorate Research Bulletin 2. Pp. 109-128. Stavanger: Norwegian Petroleum Directorate.

Feyling-Hanssen R., Funder S. \& Petersen K.S. 1983. The Lodin Elv Formation; a Plio-Pleistocene occurrence in Greenland. Bulletin of the Geological Society of Denmark 31, 81-106.

Forman S.L., Ingólfsson Ó., Gataullin V., Manley W.F. \& Lokrantz H. 1999. Late Quaternary stratigraphy of western Yamal Peninsula, Russia: new constraints on the configuration of the Eurasian ice sheet. Geology 27, 807-810. 
Forman S.L., Ingolfsson O., Gataullin V., Manley W. \& Lokrantz H. 2002. Late Quaternary stratigraphy, glacial limits, and paleoenvironments of the Marresale Area, western Yamal Peninsula, Russia. Quaternary Research 57, 355-370.

Forman S.L., Maslowski W., Andrews J.T., Lubinski D., Steele M., Zhang J., Lammers R. \& Peterson B. 2000. Researchers explore Arctic freshwater's role in ocean circulation. EOS, Transactions of the American Geophysical Union 81, 169-174.

Fyles J.G., McNeil D.H., Matthews J.V., Barendregt R.W., Marincovich L., Brouwers E., Bednarski J., Brigham-Grette J., Ovenden L.E., Miller K.G., Baker J. \& Irving E. 1998. Geology of Hvitland beds (Late Pliocene), White Point lowland, Ellesmere Island, Northwest Territories. Geological Survey of Canada Bulletin 512, 1-35.

Grosswald M.G. 1980. Late Weichselian ice sheets of northern Eurasia. Quaternary Research 13, 1-32.

Grosswald M.G. 1998. Late Weichselian ice sheets in Arctic and Pacific Siberia. Quaternary International 45/46, $3-18$.

Hart J.K. 1994. Till fabric associated with deformable beds. Earth Surface Processes and Landforms 19, 15-32.

Hart J.K \& Rose J. 2001. Approaches to the study of glacier bed deformation. Quaternary International 86, 45-58.

Hjort C. \& Funder S. 2008. Mountain derived versus shelf based glaciations on the western Taymyr Peninsula. Polar Research 27, 273-279 (this issue).

Hjort C., Möller P. \& Alexanderson H. 2004. Weichselian glaciation of the Taymyr Peninsula, Siberia. In J. Ehlers \& P.L. Gibbard (eds.): Quaternary glaciations-extent and chronology. Part I. Europe. Pp. 359-367. Amsterdam: Elsevier.

Jakobsson M. \& Cherkis N. (compilers) 2001. International bathymetric chart of the Arctic Ocean. Version 1.0. Accessed on the internet at http://www.ngdc.noaa.gov/mgg/ bathymetry/arctic/arctic.html on 11 July 2001.

Jakobsson M., Cherkis N., Woodward J., Coakley B. \& Macnab R. 2000. A new grid of Arctic bathymetry: a significant resource for scientists and mapmakers. EOS, Transactions of the American Geophysical Union 81, 89, 93, 96.

Jakobsson M., Løvlie R., Arnold E.M., Backman J., Polyak L., Knutsen, J.-O. \& Musatov E. 2001. Pleistocene stratigraphy and palaeoenvironmental variation from Lomonosov Ridge sediments, central Arctic Ocean. Global and Planetary Change 31, 1-22.

Jakobsson M., Polyak L., Edwards M., Kleman J. \& Coakley B. 2008. Glacial geomorphology of the central Arctic Ocean: the Chukchi Borderland and the Lomonosov Ridge. Earth Surfaces Processes and Landforms $33,526-545$.

Kind N.V. \& Leonov B.N. (eds.) 1982. Antropogen Tajmyra. (The Antropogene of the Taymyr Peninsula.) Moscow: Nauka.

King C. 1989. Cenozoic of the North Sea. In D.G. Jenkins \& J.W. Murray (eds.): Stratigraphical atlas of fossil foraminifera, 2nd edition. Pp. 418-489. Chichester, UK: Ellis Horwood Limited.
Knies J., Kleiber H.-P., Matthiessen J., Müller C. \& Nowaczyk N. 2001. Marine ice-rafted debris records constraining the maximum extent of Saalian and Weichselian ice-sheets along the northern Eurasian margin. Global and Planetary Change 31, 45-64.

Knudsen K.L. \& Asbjörnsdóttir L. 1991. Plio-Pleistocene foraminiferal stratigraphy and correlation in the central North Sea. Marine Geology 101, 113-143.

Lambeck K. \& Chappell J. 2001. Sea level change through the last glacial cycle. Science 292, 679-686.

Lambeck K., Purcell A., Funder S., Kjær K.H., Larsen E. \& Möller P. 2006. Constraints on the Late Saalian to Early Middle Weichselian ice sheet of Eurasia from field data and rebound modelling. Boreas 35, 539-575.

Larsen E., Kjær K.H., Demidov I.N., Grøsfjeld K., Houmark-Nielsen M., Jensen M., Linge H. \& Lyså A. 2006. Late Pleistocene glacial and lake history of northwestern Russia. Boreas 35, 394-424.

Lokrantz H., Ingólfsson Ó. \& Forman S.L. 2003. Glaciotectonised Quaternary sediments at Cape Shpindler, Yugorski Peninsula, Arctic Russia: implications for glacial history, ice-movements and Kara Sea ice sheet configuration. Journal of Quaternary Research 18, 527-543.

Mark D.M. 1973. Analysis of axial orientation data, including till fabrics. Geological Society of America Bulletin 84, 1369-1374.

McNeil D.H. 1990. Tertiary marine events of Beaufort-Mackenzie Basin and correlation of Oligocene to Pliocene marine outcrops in Arctic North America. Arctic 43, 301-313.

Mirošnikov [Mirochnikov] L.D. 1959. Cetvertičnye otloženija i nekotorye čerty geomorfologii poluostrova Čeluskin. (Quaternary deposits and some of the geomorphological features of Cheluskin Peninsula.) Bulletin of the Leningrad State University, Series of Geology and Geography 2, 11-21.

Möller P., Bolshiyanov D.Y. \& Bergsten H. 1999. Weichselian geology and palaeoenvironmental history of the central Taymyr Peninsula, Siberia, indicating no glaciation during the last global glacial maximum. Boreas 28, 92-114.

Möller P., Lubinski D., Ingólfsson Ó., Forman S.L., Siedenkrantz M-S., Bolshiyanov D.Y., Lokrantz H., Antonov O., Pavlov M., Ljung K., Zeeberg J.J. \& Andreev A. 2006. Severnaya Zemlya, Arctic Russia: a nucleation area for Kara Sea ice sheets during the Middle to Late Quaternary. Quaternary Science Reviews 25, 2894-2936.

Molodkov A. 1988. ESR dating of Quaternary shells: recent advances. Quaternary Science Reviews 7, 477-484.

Molodkov A., Dreimanis A., Ăboltiņš O. \& Raukas A. 1998. The ESR age of Portlandia arctica shells from glacial deposits of central Latvia: an answer to a controversy on the age and genesis of their enclosing sediments. Quaternary Science Reviews 17, 1077-1094.

Murray A.S., Marten R., Johnston P. \& Martin A.J. 1987. Analysis for naturally occurring radionuclides at 
environmental concentrations by gamma spectrometry. Journal of Radioanalytical and Nuclear Chemistry 115, 263-288.

Murray A.S. \& Wintle A.G. 2000. Luminiscense dating of quartz using an improved single-aliquot regenerative-dose protocol. Radiation Measurements 32, 57-73.

Olley J.M., Murray A.S. \& Roberst R.G. 1996. The effects of disequilibria in uranium and thorium decay chains on burial dose rates in fluvial sediments. Quaternary Geochronology 15, 751-760.

Pedersen A.M. 1995. The Lower Pleistocene in the North Sea. Geological Survey of Denmark, series C13.

Peltier W.R. 1994. Ice age paleotopography. Science 265, 195-201.

Polyak L., Edwards M.H., Coakley B.J., Jakobsson M. 2001. Ice shelves in the Pleistocene Arctic Ocean inferred from glaciogenic deep-sea bedforms. Nature 410, 453-457.

Puminov A.P. 1952. Vešestvennyj sostav i uslovija formirovanija mezozojskih i kajnozojskih otloženij severa centralnoj Sibiri. (Composition and development of the Mesozoic and Cenozoic deposits of the central Siberian north.) Trudy Naučno-issledovatel'skogo Instituta Geologii Arktiki 24. Moscow: Glavsevmorput.

Ravič M.G. 1950. Geologičeskoe stroenie severnoj časti Tajmyrskogo poluostrova. (Geological structure of the Taymyr Peninsula, northern part.) Trudy Naučno-issledovatel'skogo Instituta Geologii Arktiki 6. Moscow: Glavsevmorput.

Saks V.N. 1953. Čtvertičnyj period v Sovetskoj Arktike. (The Quaternary period in the Soviet Arctic.) Leningrad: Vodtransizdat.

Seidenkrantz M.-S. 1992. Plio-Pleistocene foraminiferal paleoecology and stratigraphy in the northernmost North Sea. Journal of Foraminiferal Research 22, 363-378.

Seidenkrantz M.-S. 1995. Cassidulina teretis Tappan and Cassidulina neoteretis new species (Foraminifera): stratigraphic markers for deep sea and outer shelf areas. Journal of Micropalaeontology 14, 145-157.

Seidenkrantz M.-S. \& Knudsen K.L. 1994. Marine high resolution records of the last interglacial in northwest Europe: a review. Géographie physique et Quaternaire 48, 157-168.

Šnejder [Schneider] G.V. 1989. Stratigrafija kajnozojskih otloženij i nekotore čerty rel'efa severovostočnoj okonečnosti Tajmyrskogo Poluostrova. (Stratigraphy of Cenozoic deposits of some topographic features of the Taymyr Peninsula, north-eastern extremity.) $P G O$ Sevmorgeologija 1989, 35-48. Leningrad.
Siegert M.J. \& Dowdeswell J.A. 2004. Numerical reconstructions of the Eurasian Ice Sheet and climate during the Late Weichselian. Quaternary Science Reviews 23, 1273-1283.

State geological map of the Russian Federation 2000. Explanatory note. Taymyr series, scale $1: 2000000$, nos. T-47-XXVIII, XXIV, XXX (Moga River), T-48-XIX, XX, XXI (polar station Cheluskin), T-48-XXII, XXIII, XXIV (Samuila Island), T-48-XXV, XXVI, XXVII (Lodochnikova Plateau). St. Petersburg: A. P. Karpinsky All-Russian Geological Research Institute.

Steinsund P.I., Polyak L., Hald M., Mikhailov V. \& Korsun S. 1994. Distribution of calcareous benthic foraminifera in recent sediments of the Barents and Kara Sea. In P.I. Steinsund (ed.): Benthic foraminifera in surface sediments of the Barents and Kara Seas: modern and late Quaternary application. Pp. 61-102. PhD thesis, University of Tromsø.

Svendsen J.I., Alexanderson H., Astakhov V.I., Demidov I., Dowdeswell J.A., Funder S., Gataullin V., Henriksen M., Hjort C., Houmark-Nielsen M., Hubberten H.W., Ingólfsson Ó., Jakobsson M., Kjær K.H., Larsen E., Lokrantz H., Lunka J.P., Lysa A., Mangerud J., Matiouchkov A., Murray A., Möller P., Niessen F., Nikolskaya O., Polyak L., Saarnisto M., Siegert C., Siegert M.J., Spielhagen R.F. \& Stein R. 2004. Late Quaternary ice sheet history of northern Eurasia. Quaternary Science Reviews 23, 1229-1271.

Svendsen J.I., Astakhov V.I., Bolshiyanov D.Y., Demidov I., Dowdeswell J.A., Gataullin V., Hjort C., Hubberten H.-W., Larsen E., Mangerud J., Melles M., Möller P., Saarnisto M. \& Siegert M.J. 1999. Maximum extent of the Eurasian ice sheets in the Barents Sea region during the Weichselian. Boreas 28, 234-242.

ten Dam A. \& Reinhold T. 1941. Die stratigraphische Gliederung des Niederländischen Plio-Pleistozäns nach Foraminiferen. (Stratigraphy of the Dutch Plio-Pleistocene based on foraminfera.) Mededeelingen van de Geologische Stichting, Series C-V, 1 .

Urvantsev N.N. 1931. Četvertičnoe oledenenie Tajmyra. (Quaternary glaciation of Taymyr.) Bulleten' komissii po izučeniju četvertičnogo perioda 3, 23-42.

van Voorthuysen J.H. 1958. Les foraminifères Mio-Pliocène et Quaterinaire du Kruisschans. (The Mio-Pliocene and Quaternary foraminifera from Kruisschans.) Institut Royal des Sciences Naturelles de Belgique, Memoires 142.

Weaver A.J. 1995. Driving the ocean conveyor. Nature 378, 135-136. 